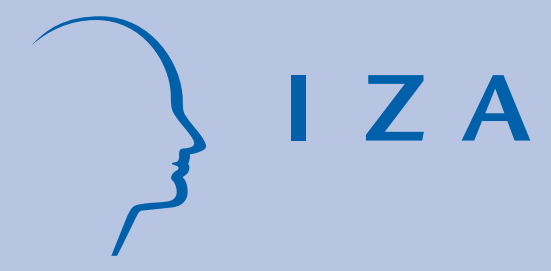

IZA Policy Paper No. 78

Transatlantic Trade and Investment Partnership:

Sectoral and Macroeconomic Perspectives for Germany, the EU and the US

Tony Irawan

Paul J.J. Welfens

January 2014 


\title{
Transatlantic Trade and Investment Partnership: Sectoral and Macroeconomic Perspectives for Germany, the EU and the US
}

\author{
Tony Irawan \\ Schumpeter School and EIIW, University of Wuppertal \\ and Bogor Agricultural University \\ Paul J.J. Welfens \\ EIIW and Schumpeter School, University of Wuppertal, \\ Sciences Po, IZA and AICGS/Johns Hopkins University
}

\author{
Policy Paper No. 78 \\ January 2014
}

IZA

P.O. Box 7240

53072 Bonn

Germany

\author{
Phone: +49-228-3894-0 \\ Fax: +49-228-3894-180 \\ E-mail: iza@iza.org
}

The IZA Policy Paper Series publishes work by IZA staff and network members with immediate relevance for policymakers. Any opinions and views on policy expressed are those of the author(s) and not necessarily those of IZA.

The papers often represent preliminary work and are circulated to encourage discussion. Citation of such a paper should account for its provisional character. A revised version may be available directly from the corresponding author. 


\section{ABSTRACT \\ Transatlantic Trade and Investment Partnership: Sectoral and Macroeconomic Perspectives for Germany, the EU and the US}

The EU and the US have started negotiations on a Transatlantic Trade and Investment Partnership Agreement (TTIP) which could bring a considerable increase of exports and output as well as changes in the composition of output and employment. Thus export simulation studies in combination with input output analysis and employment analysis is useful. In the analysis presented the focus is mainly on sectoral output and employment effects where the key sectors are the automotive sector, chemical industry, information and communication technology production, pharmaceuticals and machinery and equipment. Backward sector links are analyzed and found to be quite important in the automotive sector, the chemical industry, the machinery and equipment sector in both Germany and the US; in Germany also in ICT production. However, most of the observed sectors have weak forward linkage. Input output analysis is also used to identify employment effects in various sectors: the pure employment effect of a 20\% export expansion in Germany amounts to about 800 000 new jobs. Looking only at the US and German perspective turns out to be misleading the high imports of intermediate inputs of German firms from EU partner countries suggests that a comparison EU-US is analytically required for some key issues and that considering the effects on EU partners is also useful. There is a host of key policy issues, including the issue of extended sustainability reporting.

JEL Classification: F15, F16, F21, J21

Keywords: TTIP, trade, foreign direct investment, labor, input output analysis, employment

Corresponding author:

Paul J.J. Welfens

President of the European Institute for International Economic Relations (EIIW)

University of Wuppertal

Rainer-Gruenter-Str. 21

42119 Wuppertal

Germany

E-mail:welfens@eiiw.uni-wuppertal.de

\footnotetext{
Forthcoming in the Journal International Economics and Economic Policy, 2014. Preliminary, comments welcome. Paul Welfens acknowledges inspiring discussions with Robert Lawrence, Kennedy School of Government. The usual disclaimer applies.
} 


\section{Content}

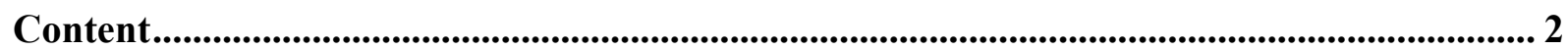

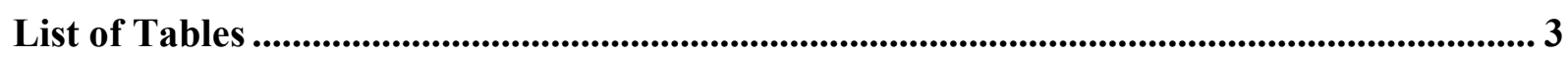

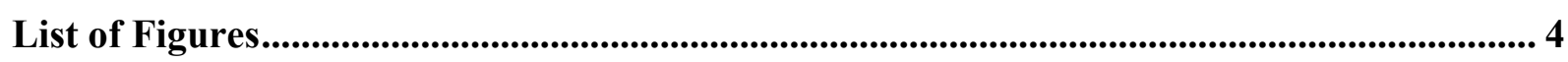

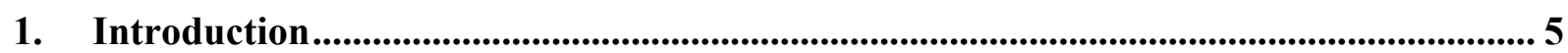

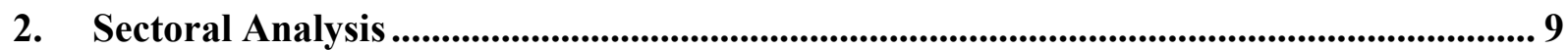

3. Machinery \& Equipment Sector and FDI Perspectives ................................................ 23

4. Policy Issues .................................................................................................................................................. 31

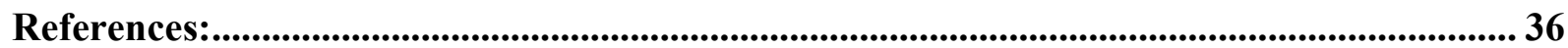

Appendix 1: Detailed consumption of intermediate inputs (observed sectors in Germany) -

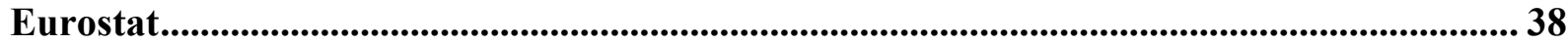

Appendix 2: Detailed consumption of intermediate inputs (observed sectors in the US) -

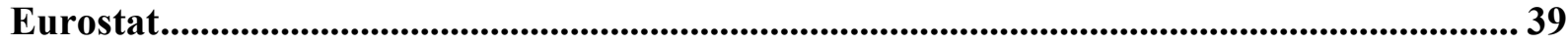

Appendix 3: Detailed consumption of intermediate inputs (observed sectors in the EU) -

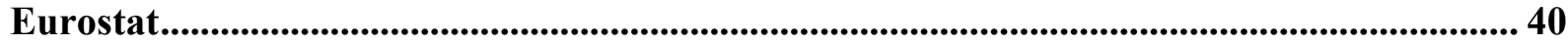

Appendix 4: Detailed consumption of intermediate inputs of the machinery and equipment

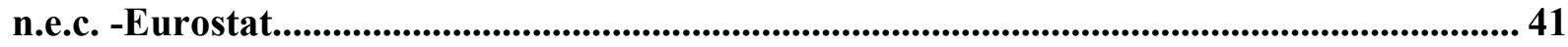

Appendix 5: The impact of $20 \%$ increase in export of each observed sector on sectoral employment ......................................................................................................................................... 42

Appendix 6: The impact of an increase in exports due to TTIP agreement on Germany sectoral output and employment ............................................................................................................. 44

Appendix 7: US FDI Outward to the European Union Countries .......................................... 46

Appendix 8: US FDI Inward from the European Union Countries......................................... 47

Appendix 9: US FDI Outward to Germany (Historical Basis / Stock) ................................... 48

Appendix 10: US FDI Inward from Germany (Historical Basis / Stock) ................................. 49

Appendix 11: Sector' share in value added as a percent of total value added -Eurostat..... 50

Appendix 12: Sector' expenditure on Scientific Research and Development Services (as a percentage of total intermediate input consumption) -Eurostat ...........................................5 51

Appendix 13: Detailed Structure of Five Observed Sectors ...................................................... 54 


\section{List of Tables}

Table 1: Backward and Forward Linkage Indicators of Selected Sectors; Germany, US, EU.... 15

Table 2: The impact of $20 \%$ increase in export of chemicals and chemical products in Germany 16

Table 3: The impact of $20 \%$ increase in export of computer, electronic and optical products in Germany....

Table 4: The impact of $20 \%$ increase in export of motor vehicles, trailers and semi-trailers in Germany.....

Table 5: The impact of 20\% increase in export of basic pharmaceutical products and pharmaceutical preparations in Germany ....

Table 6: The impact of $20 \%$ increase in export of machinery and equipment n.e.c. in Germany

Table 7: The impact of an increase in exports due to TTIP agreement on German sectoral output and labor (selected sector); implications of export growth based on Felbermayr et al. (2013)

Table 8: Trade Balance between Germany and the US (selected sectors); millions of US \$..... 22

Table 9: US FDI Outward to Germany (in percent relative to total FDI).................................... 26

Table 10: US FDI Inward from Germany (in percent relative to total FDI)............................ 26 


\section{List of Figures}

Figure 1: Structure of input of selected sectors in Germany ..................................................... 9

Figure 2: Structure of input of selected sectors in the US ......................................................... 10

Figure 3: Structure of input of selected sectors in the EU......................................................... 11

Figure 4: Structure of output of selected sectors in Germany .................................................... 12

Figure 5: Structure of output of selected sectors in the US....................................................... 13

Figure 6: Structure of output of selected sectors in the EU....................................................... 14

Figure 7: Export of Germany to the US (Selected sectors) ........................................................ 21

Figure 8: Export of the US to Germany (Selected sectors) ........................................................ 22 


\section{Introduction}

The EU and the US have started transatlantic trade negotiations on a Transatlantic Trade and Investment Partnership (TTIP) in 2013 and since both partners account for about half of the global income and more than $25 \%$ of global trade one may anticipate considerable impulses from a broad agreement; based on WTO figures the share of the US in global trade was $10.5 \%$, that of the EU 15\%. TTIP is expected to not only cut the already low tariff rates on industrial products considerably but also reduce nontariff barriers. Moreover, to the extent that additional elements of such an agreement should facilitate transatlantic trade in the crucial fields of both the manufacturing industry and services considerable trade, output and employment gains can be expected for the both US and the EU. The European Commission has commissioned one major study on the economic effects of TTIP, namely Francois et al. (2013) who come up with suggested economic gains of about $0.5 \%$ of GDP for both the US and the EU; the authors use the GTAP model and some CGE modelling. The subsequent analysis raises some doubts about the rather low benefits derived in this study - the final calculus can be made, of course, only once the negotiations have been completed and detailed results are known. Felbermayr et al. (2013) has presented particular results for Germany, namely based on the assumption that the TTIP will bring the same average trade liberalization effects as previous German free trade agreements with other partners; this is a rather pragmatic assumption - the gain for Germany in terms of output is rather modest while that for the US is very high. As regards employment effects IFO (2013) derives a surprising result, namely that the rise of unskilled workers wages will be higher than for skilled workers in Germany.

In the subsequent analysis we shed light on these conjectures and derive somewhat different results. Moreover, we present findings for key sectors in the US, Germany and the EU, respectively; this includes simulation results and calculations made on the basis of the Input Output Analysis for 2009 and the TIVA database from OECD/World Bank which provides trade in value added for 2005, 2008 and 2009. We thus look at selected key sectors of industry in the US, Germany and the EU, respectively. Looking only at the US and Germany would be misleading even if one would be mainly interested in effects for Germany and the US. The broader EU picture is needed not only because TTIP means trade liberalization of the EU and the US, it is also crucial to take into account that a rise of German exports to the US for example will generate considerable intra-EU reallocation of resources since certain German sectors rely strongly on imported intermediate inputs from EU partner countries. The same analytical logic would apply to any bilateral analysis, e.g. France and the US, UK and the US etc. - this perspective, however, is not standard in the literature. A remarkable exception is Fontagné et al. (2013): The CEPII authors focus on TTIP (including special focus on France) and present results for a reference liberalization scenario and four additional scenarios for the US, the EU27, Germany, the UK, France and Eastern European EU countries. Given the fact that the average import tariffs are 2\% for the US and 3\% for the EU - with some peaks in certain sectors - and considering the rather large non-tariff barriers (NTBs) it is adequate that the basic scenario will include assumptions about reduction of NTBs: Full phasing out of tariffs by 2025 is assumed and 
a 25\% across-the-board cut of NTBs for both the product and services sectors - except for public and audiovisual services. The authors point out that cutting NTBs in the service sector by more than $15 \%$ will also affect intra-EU trade (the assumption here is that NTBs within the EU are $15 \%$ lower than for third countries). The CGE modelling then gives as key results that US imports will increase by $7.5 \%$ until 2025, the EU27, excluding intra-EU imports, will record a plus of $7.4 \%$ and the EU27 (including intra-EU imports) should expect a plus of $2.2 \%$. The split across sectors is rather uneven in exports: the total for the US is $10.1 \%,+12.6 \%$ for US agriculture, $+12.2 \%$ for US industry, $+3.2 \%$ for services. The figures for the EU27 exports excluding intra-EU - are $+7.6 \%$ (total), $7 \%$ for EU agriculture, $8.9 \%$ for industry and $4.5 \%$ for EU services. The broadest liberalization scenario considered generates real income gains of $0.5 \%$ for both the US and the EU27; 0.5\% for Germany, 0.4\% for both the UK and France and 0.5\% for Eastern European EU accession countries while the figures in the reference scenario are somewhat lower: $0.3 \%$ for the US and the EU27, $0.3 \%$ for Germany and the UK, $0.2 \%$ for France and the accession countries.

The study of Erixon/Bauer (2010) derives several interesting findings within a rather simple and straightforward set of assumptions for an analysis that - at first glance - looks only at the effects of liberalizing trade in goods. The authors assume that all tariffs on both sides of the Atlantic are eliminated for transatlantic trade which yields certain liberalization effects; at the same time they emphasize that most trade is intra-industrial trade so that "dynamic effects", namely from enhanced competition in the integrated transatlantic market, have also to be considered: Thus it is assumed that labor productivity in sectors characterized by strong intra-industrial trade (measured by Grubel-Lloyd indices) will increase by 3.5\% and in all other sectors there will be labor productivity growth of $2 \%$. Taking into account the complementary dynamic effects implies that EU exports to the US will increase by $18 \%$ within a few years and US exports to the EU by $17 \%$. The assumptions on productivity growth of Erixon and Bauer seem to be somewhat too optimistic in the light of recent US productivity analysis: The Council of Economic Advisers noted (CEA, 2010, p. 268): “The pattern of productivity growth since 1995 is somewhat complicated. From 1996:Q1 to the last available observation (2009:Q3), it averaged 2.7 percent per year, almost equal to its rate over the immediate postwar period. But that rapid growth was concentrated in the first part of the period. In the first eight years (1996:Q1 to 2003:Q4), productivity growth averaged 3.3 percent; in the four years before the business cycle peak (2004:Q1 to 2007:Q4), it averaged only 1.7 percent.”. The Erixon/Bauer assumptions thus stand for a favorable high end scenario.

There is no doubt that a transatlantic free trade area will be an important element of the broader globalization process. While one may assume that there will be temporary trade diversion effects, positive real income effects in the EU and the US plus the presence of Asian investors in both Europe and North America could contribute to generating long term global economic gains.

While it is certainly adequate to consider dynamic economic effects of a transatlantic free trade area one also should consider in a more long term perspective the effects on transatlantic foreign direct investment (FDI). US FDI in the EU is high and so is EU FDI in the US. As regards the adjustment dynamics in individual EU countries - such as Germany, France, the UK, Italy, Spain - a comprehensive analysis will not only focus on static effects, based on existing intra-EU and 
global trade structures. Rather, one will have to ask to what extent for example higher German exports of the US in manufacturing industry will lead to more outsourcing and offshoring within the EU: German firms can be expected to particularly outsource the "lower part" (production jobs that require less knowledge or capital than the high value-added key elements of overall production of a respective good) of the value-added chain so that firms in EU partner countries will play a bigger role as intermediate product suppliers; some additional intra-EU offshoring also could occur and this could refer not only to the lower part of the value-added chain but to rather knowledge-intensive or technology elements as well - here, through its relations with subsidiaries abroad, the respective parent company will keep control over crucial elements of the value-added chain. If German firms import more intermediate inputs from EU partner countries GDP in these countries will increase and this in turn should have a positive repercussion effect on Germany’s total exports.

Moreover, plants in Germany will be able to concentrate more on complex innovative, knowledge-intensive and capital intensive elements of the value-added chain and this should contribute to a rise in the demand for skilled workers in Germany. Increased intra-EU outsourcing should, however, reduce the demand for unskilled workers in Germany. From a USGerman perspective the view adopted here suggests that transatlantic innovation dynamics will increase and to the extent that US companies and German companies generate more product innovations in the context of an integrated transatlantic market one should expect that the current account balance of the US+EU - possibly of the US and the EU - will improve in the medium term since product cycle trade will generate additional exports of US and EU firms to the rest of the world. This is the logic of the product cycle trade (Vernon, 1966) and since this approach is also linked with FDI dynamics there is an additional argument to consider the perspectives of multinational companies and international investment, respectively. With many multinational companies - often in technology-intensive production - active in the EU and the US it is clear that TTIP will enhance intra-company trade to some extent. Moreover, there could be enhanced transatlantic FDI flows where one may distinguish between greenfield investment and international mergers and acquisitions. The latter go along with a rise of the relative stock market price and international technology transfer, greenfield investments stand mainly for capital accumulation effects and enhanced technology transfer.

CGE modelling and GTAP analysis, used for example by Francois et al. (2013), is a rather static exercise as neither competition-enhancing effects nor FDI effects nor macroeconomic interdependency aspects are included. As regards the latter the point is that both the US and the EU are big economies. If TTIP raises output in the US by $1 \%$ it should increase output in the EU by about $0.3 \%$ and this will have a positive repercussion effect on the US so that the initial output effect is slightly magnified; and the same holds for an initial 1\% output increase in the EU which then will raise US output by maybe $0.2 \%$ and this in turn will have a positive feedback effect on Europe. With higher gross national income in both the EU and the US there will be an increase in per capita income on both sides of the Atlantic and this in turn will raise the demand for differentiated products whose demand is positively linked to per capita income. Thus the production of differentiated products will increase and additional impulses for product innovations will be generated. An increasing production of differentiated products will require 
more skilled labor and often also more sophisticated machinery and equipment - broadly defined; this could include the additional use of information and communication technology products whose demand in any case is expected to increase if FDI dynamics are positive on both sides of the Atlantic. Big companies with more international production will have to use more ICT equipment to accommodate the required additional complex controlling and production tasks. From this perspective, it is also quite important to consider the role of machinery and equipment production; in this respect Germany is well positioned since exports of machinery and equipment (broadly defined) relative to GDP reached about 14\% in 2007 (IWD, 2013).

From this perspective it is natural in a sector analysis to focus not only on key sectors of exports and employment, namely automotive and chemicals, rather one should also look at technology intensive sectors such as the pharmaceutical and ICT sectors; finally, the machinery and equipment (n.e.c) sector is of particular interest - certainly from a German/EU/US perspective. Thus we have five important sectors on which our analysis will put a particular focus. In this analysis we cannot take into account all the key aspects mentioned as crucial in a medium-term or a long-term perspective. However, we will add new insights into the crucial transatlantic analysis and the on-going policy debate.

Finally, one may ask to what extent TTIP will reinforce integration and competition dynamics within the EU single market and thereby contribute to price convergence across EU countries. Bradford/Lawrence (2004) have pointed out that looking at international price convergence for the US, Japan, Canada, Australia and five EU countries (Germany, Belgium, Italy, Netherlands, UK) the ratio of expenditure weighted producer price to the lowest price in the group of nine countries was rather low in the US and Canada in 1990 and 1999; the year 1999 was seven years after the start of the EU single market. With the creation of a common transatlantic market one would expect that the price convergence of EU countries would be reinforced. There is, however, a caveat, namely to the extent that innovation dynamics would be reinforced by TTIP in the EU and the US: more Schumpeterian dynamics could reinforce the opportunities for price segmentation on the basis of patent protection which plays a strong role in certain sectors.

The subsequent analysis first puts a focus on sectoral differences in the US, Germany and the EU (Section 2). This is followed by a closer look at the investment dynamics and the role of foreign direct investment in a transatlantic perspective. The final section draws some policy conclusions. It must be emphasized that definitions of sectors in various statistical categories are not always equal (see Appendix 13). 


\section{Sectoral Analysis}

The analysis is focused on five sectors, namely the chemical and chemical products sector (chemical sector), the computer, electronic and optical products sector (ICT manufacturing sector), the motor vehicles, trailers and semi-trailers sector (automotive sector), the basic pharmaceutical products and pharmaceutical preparations sector (pharmaceutical sector) and the machinery and equipment, n.e.c. sector (machinery sector). Before we proceed to the analysis of the impact of TTIP, we firstly analyse the structure of input and output of five observed sectors in both Germany and the US. We use Input-Output (IO) Tables of both countries in the year 2009 which can be accessed from Eurostat IO Database, trade statistics from WITS and WTOOECD TIVA Database.

Figure 1 suggests that all five observed sectors in Germany have relatively high local contents. Among the five observed sectors, the machinery sector has the highest domestic content, approximately 77 percent. The consumption of domestic intermediate input by the automotive sector and the ICT manufacturing sector are slightly lower than the machinery sector, with 73 percent and 71 percent respectively. Two other sectors, the chemical sector and the pharmaceutical sector, have lower still local contents with 64 percent and 65 percent.

Figure 1: $\quad$ Structure of input of selected sectors in Germany

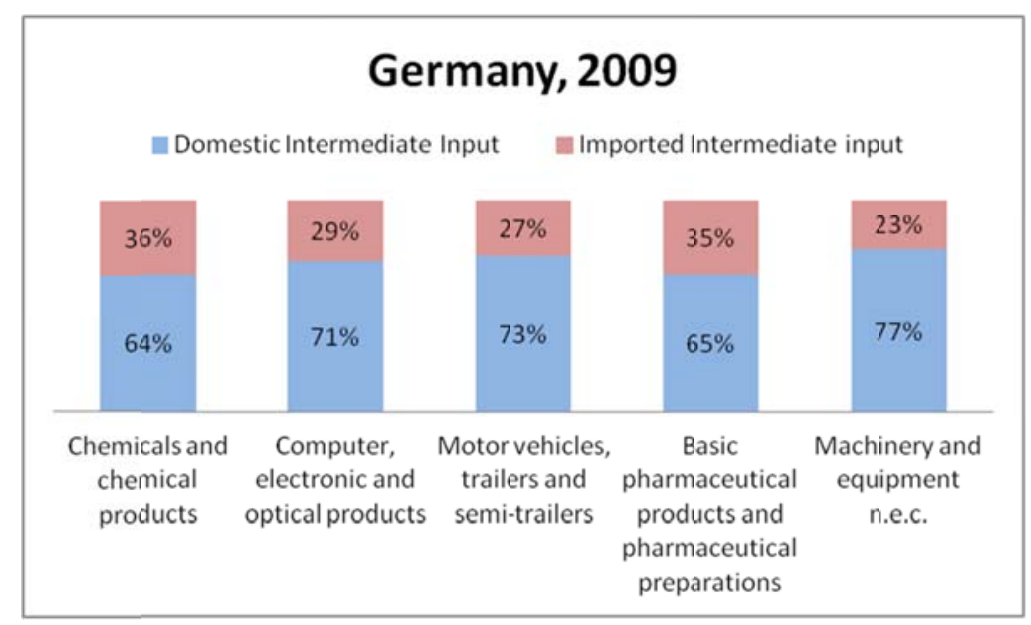

Source: Eurostat

Five observed sectors in the US also have high local contents. Moreover, the proportion of domestic intermediate inputs is much higher than the similar sector in Germany. Figure 2 suggests that the chemical sector has the highest local contents relative to the other four sectors and has a higher proportion than the similar sector in Germany. The US chemical sector uses a very high level of domestic intermediate inputs, approximately 88 percent of total intermediate used. It is 24 percent higher than the similar sector in Germany. Other sectors also seem superior to the similar sector in Germany in terms of the use of domestic intermediate inputs. However, one may argue that peer-to-peer comparison between those four sectors in Germany and the US 
could lead to misleading conclusions. Thus, we also present the structure of input of five observed sectors in the EU.

Figure 2: $\quad$ Structure of input of selected sectors in the US

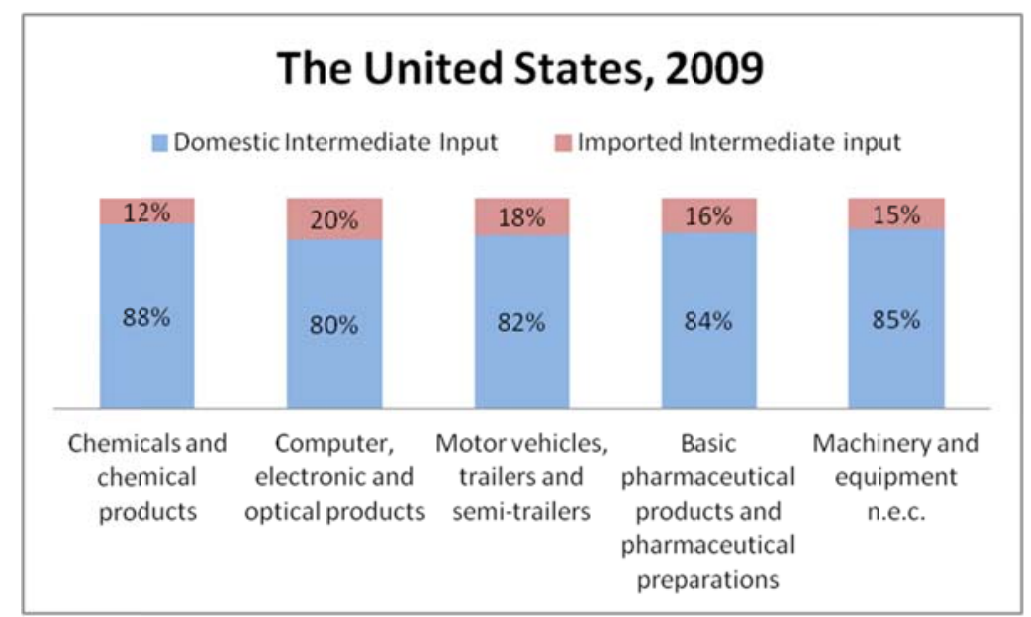

Source: Eurostat

The structure of input of the five observed sectors in the EU is broadly similar to the structure of the same sectors in the US. The consumption of domestic intermediate input by the chemical sector in the EU is only 1 percent lower than the US chemical sector. The proportion of domestic intermediate inputs in ICT manufacturing sector is only 2 percent lower than the similar sector in the US. Figure 3 also suggests that the automotive sector in the EU has higher local contents than the US automotive sector. It accounts for as much as 93 percent (11 percent higher than the US) of total intermediate inputs used. Two other sectors also have higher local contents relative to the similar sectors in the US. The pharmaceutical sector in the EU has (4 percent) higher local contents than the US pharmaceutical sector. The consumption of domestic intermediate inputs by the EU machinery sector is also higher than the US machinery sector.

By using both a symmetric IO Table for domestic outputs and an IO Table for imported products, we can get detailed information regarding the linkage between the five observed sectors and its downstream sectors. Appendix 1 and Appendix 2 present producers of both domestic and imported intermediate inputs that are used by the five observed sectors on a sectoral basis. Generally, if we compare the chemical sectors in Germany and the US, we find some similarities. Firstly, three important sectors which produce intermediate input for the chemical sector are the chemical sector, the coke and refined petroleum products and wholesale trade services, with the exception of motor vehicles and motorcycles. Secondly, the chemical sector in both countries has strong intra-industry linkage. In other words, the chemical sector uses a considerable amount of intermediate inputs which are produced by the chemical sector. For instance, manufacture of basic inorganic chlorine and alkalis uses a significant amount of soda ash. Both producers are included in the chemical sector. 
Figure 3: $\quad$ Structure of input of selected sectors in the EU

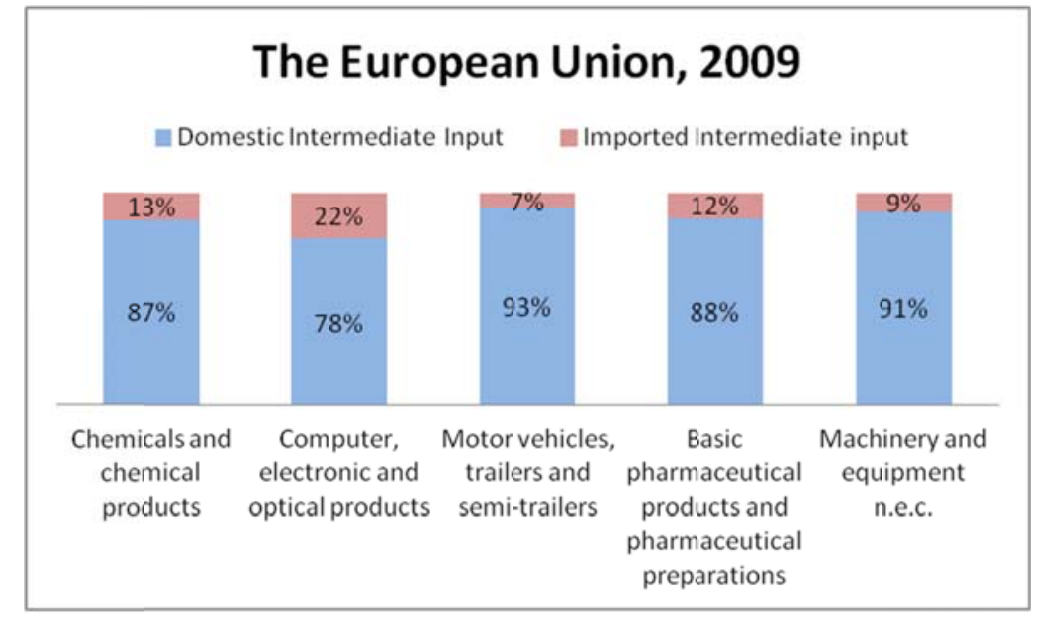

Source: Eurostat

Despite those similarities, there is one substantial difference between the chemical sectors of Germany and the US. The US chemical sector consumes a significant amount of intermediate inputs which are produced by the domestic chemical sector (intra-industry). It accounts for about 36.2 percent of total intermediate inputs used. Meanwhile, 22.8 percent of total intermediate inputs which are used by the German chemical sector are imported from other countries. These imply that the German chemical sector is more vulnerable to external shocks relative to the US chemical sector.

Similar with the chemical sector, the German ICT manufacturing sector and the pharmaceutical sector also have strong dependency with the similar sectors of other countries. Approximately 17.9 percent of total intermediate inputs which are used by the German ICT manufacturing sector are imported from the similar sector in other countries. Meanwhile, only about 9.8 percent of total intermediate inputs are produced by domestic ICT manufacturing companies. Similar figures can also be seen in the German pharmaceutical sector. Imported pharmaceutical products which are used as intermediate inputs by pharmaceutical sector accounts for as much as 10.3 percent, or about 3.1 percent higher than domestic pharmaceutical products. Moreover, those two sectors in Germany are also unique since the most important intermediate input producer is not the sector itself. The wholesale trade services, except for the motor vehicles and motorcycles sector, is the most important downstream sector for the ICT manufacturing sector. Meanwhile, the sewerage, waste collection and disposal activities etc sector is the most important downstream sector for the pharmaceutical sector.

Unlike the previous three sectors, the German and the US automotive sectors have similar input structures. The automotive sector and the fabricated metal products sector are two main important sectors that produce intermediate inputs for the automotive sector. Moreover, the automotive sector in both Germany and the US use a higher percentage of intermediate inputs from the domestic automotive sector relative to the imported intermediate inputs. Similar figures can also be found in the machinery sector. Both the German and the US machinery sector use a 
higher proportion of intermediate inputs from the domestic machinery sector relative to the products of the foreign machinery firms. However, the machinery sector itself is not the most important downstream sector for the US machinery sector. This pattern is completely different when compared to the same sector in Germany. More than 20 percent of the total intermediate inputs used by the German machinery sector is produced by the German machinery sector itself. Some special aspects of this sector will be picked up on later in this paper.

Similar with our previous argument, we also use the EU automotive sector as a comparison. Appendix 3 shows the detailed intermediate input consumption by the five observed sectors in the EU. In general, the structure of input is broadly similar with the counterpart sectors in the US, except for the ICT manufacturing sector. The most important intermediate input for the ICT manufacturing sector in the EU is produced by the ICT manufacturing sector in other countries (imported ICT manufacturing products). It is estimated to be as much as 15.8 percent of total intermediate inputs used by the ICT manufacturing sector.

Another aspect that is also important to be analysed is the structure of output. Felbermayr et al. (2013) found that Germany and the US have different economic orientations. Germany has an export oriented orientation, whereas the US produces goods and services to satisfy its domestic demand. Our findings generally support Felbermayr et al. (2013) in which all the five observed sectors in Germany are export oriented. Figure 5 suggests that 67 percent of total output in the German chemical sector is exported abroad. The same patterns are also found in three other observed sectors in Germany. However, most of the products are exported to other EU countries, except for the machinery sector. The output of the German machinery sector is exported mostly to non-European Union Member States.

Figure 4: $\quad$ Structure of output of selected sectors in Germany

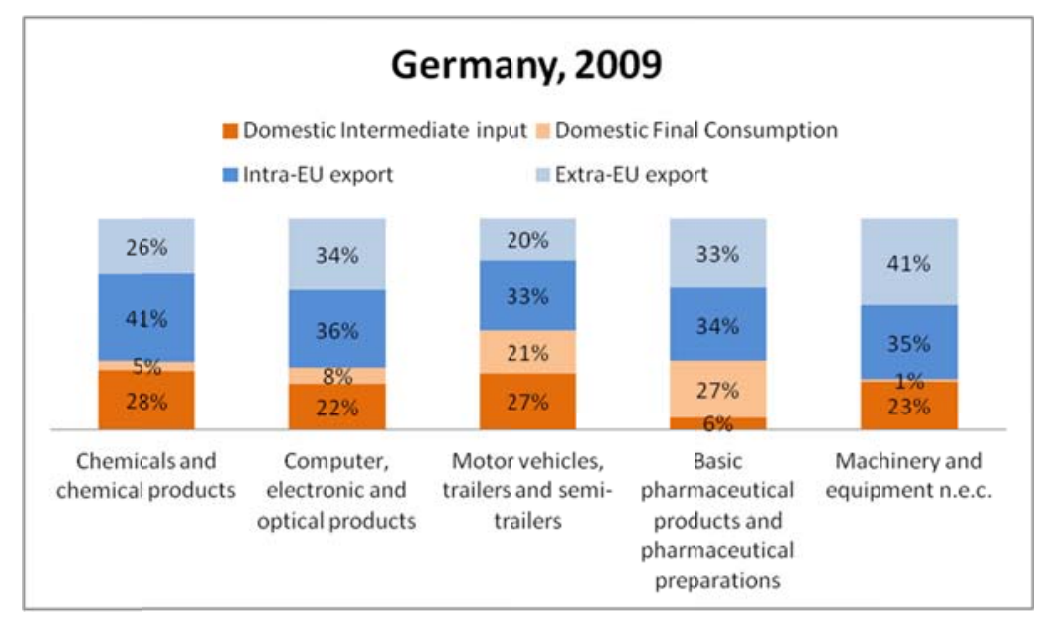

Source: Eurostat

A completely different picture is found in the US economy. Figure 5 shows that only a small percentage of the output in the five observed sectors are exported abroad, except for the machinery sector. Approximately 17 percent of total output in the US chemical sector is exported abroad. More than half of total production in this sector is consumed by other sectors as intermediate inputs. Figure 5 also suggest that the orientation of the US pharmaceutical sector is 
to satisfy the domestic final demand since 60 percent of the total output is consumed by the domestic final users. Among the five observed sectors, the machinery sector has the highest export proportion, as much as 42 percent. This is extremely higher than the other four sectors. However, the market orientation of the US machinery sector is also to satisfy domestic demand since 58 percent of total output is consumed as intermediate inputs by other domestic sectors and final uses.

Figure 5: $\quad$ Structure of output of selected sectors in the US

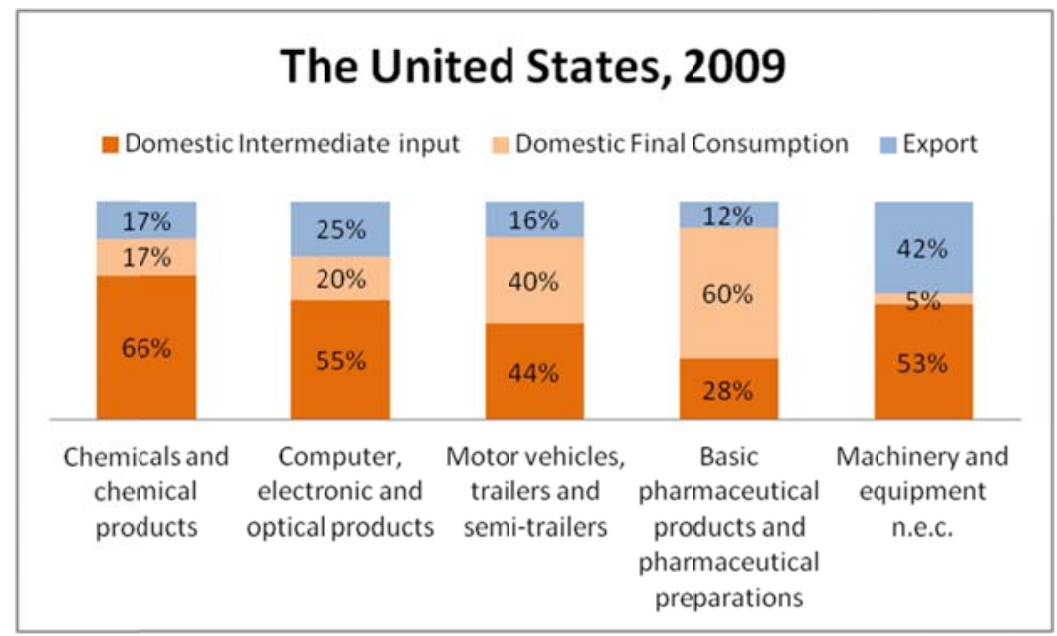

Source: Eurostat

Since we cannot use peer-to-peer comparison between Germany and the US, Figure 6 presents the structure of output of five observed sectors in the EU. Generally, the figure seems to be more similar to the US economy than the German. More than half of total output in four observed sectors is consumed by the domestic economic agents both as intermediate input and final use. Moreover, the machinery sector has the highest proportion in terms of export among the five observed sectors. The proportion of output which is exported abroad by the machinery sector in the EU is relatively higher than the similar sector in the US. A similar pattern is also found in the ICT manufacturing sector. The share of export to total output of the EU ICT manufacturing sector is much higher than the similar sector in the US. 
Figure 6: $\quad$ Structure of output of selected sectors in the $\mathbf{E U}$

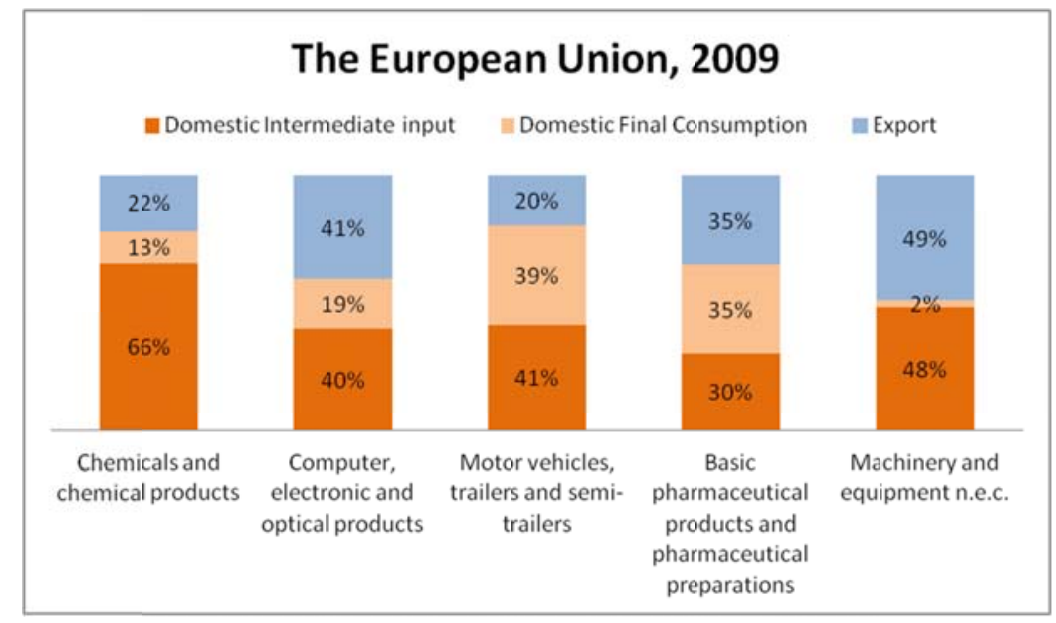

Source: Eurostat

Another important aspect to be analysed is the importance of the observed sector within the economy. Therefore, we calculate forward linkage and backward linkage (index) in order to measure the multiplier effect in the downstream sectors and upstream sectors if the sector experiences higher export. A value greater than 1 means that each additional unit of production in the sector will lead to an increase of income generating activities in other sectors above the typical increase due to the extra unit of production. Moreover, we also present the share of sectoral value added relative to total value added (GDP). Since there is always multiple counting in the IO Table, total value added is used as a proxy of GDP. This indicator shows the contribution of each observed sector on national output.

Table 1 suggests that most of the observed sectors have a relatively strong backward linkage, except for the pharmaceutical sector. In fact, the backward linkage of the German automotive sector is the fourth strongest backward linkage in the German economy after the travel agency, tour operator, and other reservation services sector (1.76), the insurance, reinsurance and pension funding services sector (1.37), and the wood and product of wood sector (1.24). The five observed sectors have a relatively weak forward linkage compared to other sectors within the German economy. Among the four sectors, the pharmaceutical sector has the weakest forward linkage, as much as 0.61 .

There are only three sectors, out of five sectors observed in the US, which have strong backward linkage, i.e. the chemical sector, the automotive sector and the machinery sector. Moreover, the automotive sector has the strongest backward linkage relative to other sectors within the US economy. The US chemical sector also has strong backward linkage, representing the third strongest backward linkage within the US economy after the basic metals sector. The machinery sector has a moderate backward linkage as much as 1.144. In term of forward linkage, there is only the chemical sector that has strong forward linkage. In fact, it is the fifth strongest forward linkage in the US economy. The other four observed sectors have forward linkage index below 1 . 
Table 1: Backward and Forward Linkage Indicators of Selected Sectors; Germany,

US, EU

\begin{tabular}{|c|c|c|c|}
\hline \multicolumn{4}{|l|}{ Backward Linkage (index) } \\
\hline Sector & Germany & US & $\mathbf{E U}$ \\
\hline Chemicals and chemical products & 1.047 & 1.228 & 1.199 \\
\hline Computer, electronic and optical products & 1.033 & 0.879 & 1.065 \\
\hline Motor vehicles, trailers and semi-trailers & 1.233 & 1.363 & 1.368 \\
\hline Basic pharmaceutical products and pharmaceutical preparations & 0.929 & 0.917 & 1.044 \\
\hline Machinery and equipment n.e.c. & 1.086 & 1.144 & 1.168 \\
\hline \multicolumn{4}{|l|}{ Forward Linkage (index) } \\
\hline Sector & Germany & US & EU \\
\hline Chemicals and chemical products & 0.970 & 1.794 & 1.581 \\
\hline Computer, electronic and optical products & 0.800 & 0.918 & 0.773 \\
\hline Motor vehicles, trailers and semi-trailers & 0.849 & 0.899 & 0.923 \\
\hline Basic pharmaceutical products and pharmaceutical preparations & 0.614 & 0.688 & 0.632 \\
\hline Machinery and equipment n.e.c. & 0.856 & 0.854 & 0.966 \\
\hline \multicolumn{4}{|l|}{ Share of sectoral value added relative to GDP $\left(V_{i}\right)$} \\
\hline Sector & Germany & US & $\mathbf{E U}$ \\
\hline Chemicals and chemical products & $1.21 \%$ & $0.96 \%$ & $0.94 \%$ \\
\hline Computer, electronic and optical products & $0.84 \%$ & $1.36 \%$ & $0.61 \%$ \\
\hline Motor vehicles, trailers and semi-trailers & $1.73 \%$ & $0.39 \%$ & $0.90 \%$ \\
\hline Basic pharmaceutical products and pharmaceutical preparations & $0.64 \%$ & $0.73 \%$ & $0.62 \%$ \\
\hline Machinery and equipment n.e.c. & $2.83 \%$ & $0.75 \%$ & $1.37 \%$ \\
\hline Sum of sectors covered & $7.25 \%$ & $4.19 \%$ & $4.44 \%$ \\
\hline \multicolumn{4}{|l|}{ Implied total weight $^{\mathrm{A})}(1+\mathrm{BL}+\mathrm{FL}) * \mathrm{~V}_{\mathrm{i}}$ : } \\
\hline - Chemicals and chemical products & $3.65 \%$ & $3.86 \%$ & $3.55 \%$ \\
\hline - Computer, electronic and optical products & $2.38 \%$ & $3.80 \%$ & $1.73 \%$ \\
\hline - Motor vehicles, trailers and semi-trailers & $5.33 \%$ & $1.27 \%$ & $2.96 \%$ \\
\hline - Basic pharmaceutical products and pharmaceutical preparations & $1.63 \%$ & $1.90 \%$ & $1.66 \%$ \\
\hline - Machinery and equipment n.e.c. & $8.33 \%$ & $2.25 \%$ & $4.29 \%$ \\
\hline
\end{tabular}

Note: ${ }^{\mathrm{A})}$ not corrected for sectoral overlap

All five observed sectors in the EU have strong backward linkage relative to other sectors within the EU economy. Moreover, the EU automotive sector has the strongest backward linkage within the EU economy. The EU chemical sector has both backward linkage and forward linkage greater than one. This means that the chemical sector has strong backward and forward linkage relative to other sectors in the EU economy. Basically, it is similar to the US chemical sector.

Table 1 also suggests that the machinery sector has a larger contribution to the GDP of Germany relative to the other four observed sectors. In fact, the contribution of the machinery sector to national GDP is the highest among German manufacturing sectors. A similar pattern is also found in the EU economy. The machinery sector has the highest contribution to the national GDP among the five observed sectors. Meanwhile, the US sectoral value added relative to GDP has a different pattern. The ICT manufacturing sector has the highest contribution to the national GDP among the five observed sectors. 
The value of backward and forward linkage index reveals that all five observed sectors are important sectors for the US, the EU and German economies. However, it does not give us detailed information regarding the economic impact of the increasing export in particular sectors. Previous literature, such as Felbermayr et al. (2013) and Francois et al. (2013), have estimated that the implementation of TTIP will increase the export of both the US and the EU. Thus, we use a multiplier matrix which is calculated from the IO Table in order to measure the sectoral impact of TTIP on the German economy. Practically, we use the estimation of Felbermayr et al. (2013) regarding the possible impact of TTIP on German export (by sector) as the shock on IO multiplier matrix. Felbermayr et al. (2013) employed CGE analysis (MIRAGE model) by using GTAP 8 data set as its database. In the report they estimated the percentage changes of total German export - by sector - to the world after the implementation of TTIP (by assuming lower trade barriers). Before we use the estimation, we have to convert GTAP sector classification into NACE Rev.2 classification which is used in the IO Table. Since Felbermayr et al. (2013) only provided percentage changes, we firstly convert the percentage changes into monetary value. Then, we can calculate percentage changes of German export (by sector) based on NACE Rev.2 classification. However, before we proceed to the results, we firstly analyze the sectoral economic impact of higher export in each observed sector. We run five simulations by assuming that the export of each observed sector increase by 20 percent. In line with Erixon/Bauer (2010), it is reasonable to consider a simulation in which exports increase by 20 percent; a plausible approach would be to consider 2/3 of results obtained as realistic. By using IO multiplier matrix, we are able to estimate the impact on sectoral output. Furthermore, we also use the product of IO multiplier matrix and labor matrix in order to calculate the impact on sectoral employment.

Table 2: $\quad$ The impact of $\mathbf{2 0 \%}$ increase in export of chemicals and chemical products in Germany

\begin{tabular}{|l|r|}
\hline \multicolumn{1}{|c|}{ Sector } & $\Delta$ Output \\
\hline Chemicals and chemical products & $16.42 \%$ \\
\hline Advertising and market research services & $1.21 \%$ \\
\hline Mining and quarrying & $1.20 \%$ \\
\hline Coke and refined petroleum products & $1.11 \%$ \\
\hline $\begin{array}{l}\text { Sewerage; waste collection, treatment and disposal activities; materials recovery; } \\
\text { remediation activities and other waste management services }\end{array}$ & $0.93 \%$ \\
\hline Natural water; water treatment and supply services & $0.72 \%$ \\
\hline Repair and installation services of machinery and equipment & $0.68 \%$ \\
\hline Paper and paper products & $0.67 \%$ \\
\hline Electricity, gas, steam and air-conditioning & $0.67 \%$ \\
\hline $\begin{array}{l}\text { Security and investigation services; services to buildings and landscape; office } \\
\text { administrative, office support and other business support services }\end{array}$ & $0.60 \%$ \\
\hline
\end{tabular}

Table 2 shows that the most affected sector due to higher export in the chemical sector is the chemical sector itself. A twenty percent increase in export is expected to raise the output of the chemical sector by 16.42 percent. The impact on other sectors is relatively small. There are only three sectors that experience an increase in output of more than 1 percent, namely the advertising and market research services sector, the mining and quarrying sector and the coke and refined 
petroleum products sector. Important to note is that Table 2 present only 10 most affected sectors out of 62 sectors in the IO Table.

Table 3: The impact of $\mathbf{2 0 \%}$ increase in export of computer, electronic and optical products in Germany

\begin{tabular}{|l|r|}
\hline \multicolumn{1}{|c|}{ Sector } & \multicolumn{1}{|c|}{ Output } \\
\hline Computer, electronic and optical products & $16.28 \%$ \\
\hline Repair services of computers and personal and household goods & $0.59 \%$ \\
\hline Employment services & $0.43 \%$ \\
\hline Advertising and market research services & $0.42 \%$ \\
\hline Architectural and engineering services; technical testing and analysis services & $0.40 \%$ \\
\hline Wholesale trade services, except of motor vehicles and motorcycles & $0.38 \%$ \\
\hline Repair and installation services of machinery and equipment & $0.37 \%$ \\
\hline Furniture; other manufactured goods & $0.37 \%$ \\
\hline Warehousing and support services for transportation & $0.37 \%$ \\
\hline Postal and courier services & $0.33 \%$ \\
\hline
\end{tabular}

Next, we run the same simulation for the ICT manufacturing sector. Table 3 suggests that all the sectors are expected to receive a very small positive impact. A twenty percent increase in the export of ICT manufacturing products is expected to increase the output of the ICT manufacturing sectors by 16.28 percent and less than 0.6 percent increase in other sectors. The advertising and market research services still one of the top ten most affected sectors.

Table 4: The impact of $\mathbf{2 0} \%$ increase in export of motor vehicles, trailers and semitrailers in Germany

\begin{tabular}{|l|r|}
\hline \multicolumn{1}{|c|}{ Sector } & \multicolumn{1}{|c|}{ Output } \\
\hline Motor vehicles, trailers and semi-trailers & $19.27 \%$ \\
\hline Wholesale and retail trade and repair services of motor vehicles and motorcycles & $3.19 \%$ \\
\hline Rubber and plastics products & $2.62 \%$ \\
\hline Basic metals & $2.51 \%$ \\
\hline Fabricated metal products, except machinery and equipment & $2.51 \%$ \\
\hline Employment services & $1.93 \%$ \\
\hline Advertising and market research services & $1.78 \%$ \\
\hline Repair and installation services of machinery and equipment & $1.56 \%$ \\
\hline Warehousing and support services for transportation & $1.42 \%$ \\
\hline Legal and accounting services; services of head offices; management consulting serv. & $1.38 \%$ \\
\hline
\end{tabular}

Unlike the previous two sectors, an increase in export of the automotive sector is expected to have a moderate positive impact on German sectoral output. The automotive sector itself is expected to have 19.27 percent higher output due to a 20 percent increase in its export. Moreover, five sectors will experience higher output of more than 2.5 percent, namely the wholesale and retail trade and repair services motor vehicles and motorcycles sector, the rubber and plastics products sector, the basic metal sector and the fabricated metal products sector. 
Interestingly, the advertising and market research services is also one of the ten most affected sectors.

Table 5: $\quad$ The impact of $\mathbf{2 0 \%}$ increase in export of basic pharmaceutical products and pharmaceutical preparations in Germany

\begin{tabular}{|l|r|}
\hline \multicolumn{1}{|c|}{ Sector } & \multicolumn{1}{|c|}{ Output } \\
\hline Basic pharmaceutical products and pharmaceutical preparations & $19.31 \%$ \\
\hline Scientific research and development services & $1.18 \%$ \\
\hline $\begin{array}{l}\text { Sewerage; waste collection, treatment and disposal activities; materials recovery; } \\
\text { remediation activities and other waste management services }\end{array}$ & $0.66 \%$ \\
\hline Advertising and market research services & $0.58 \%$ \\
\hline Employment services & $0.30 \%$ \\
\hline Paper and paper products & $0.28 \%$ \\
\hline Architectural and engineering services; technical testing and analysis services & $0.22 \%$ \\
\hline Rental and leasing services & $0.20 \%$ \\
\hline $\begin{array}{l}\text { Security and investigation services; services to buildings and landscape; office } \\
\text { administrative, office support and other business support services }\end{array}$ & $0.17 \%$ \\
\hline Legal and accounting services; services of head offices; management consulting serv. & $0.16 \%$ \\
\hline
\end{tabular}

The impact of a twenty percent increase in export of pharmaceutical products is expected to have a large impact only on the pharmaceutical sector and relatively small impacts on other sectors (see Table 5). There is only one sector, the scientific research and development services sector, which is expected to increase by more than 1 percent. We found one common similarity between the four simulations. The advertising and market research services sector is always on the top ten most affected sectors. This means that all four observed sectors have a strong linkage with the advertising and market research services sector.

Similar with previous simulations, a twenty percent increase in export of machinery products is expected to have a significant impact on the machinery sector itself. Even though not as big as the impact of an increase in the export of automotive products, there are at least 7 sectors that are expected to have an increase of more than 1 percent in their output (see Table 6). Interestingly, the impact on the employment services sector is quite significant at more than 2 percent. It is similar with other simulations except for the first simulation (the chemical sector). However, the linkage of the machinery with the advertising and market research services is pretty weak since the sector is not on the top-ten list.

As previously mentioned, we also calculate the impact of each simulation on sectoral employment. Appendix 5 shows that a 20 percent increase in export of the German chemical sector is expected to create 129,327 new jobs across a number of sectors. Most of the new jobs are created in the chemical sector, followed by the security and investigation services sector. Interestingly, seven out of ten most affected sectors in terms of sectoral employment are services sectors. A similar impact can also be seen in the second simulation. A twenty percent increase in the export of the ICT manufacturing sector is expected to create about 115,972 new jobs. More 
than half of the new jobs are created in the ICT manufacturing sector, followed by the wholesale trade services sector. There is only one manufacturing sector in the top ten most affected sectors, the fabricated metal products sector.

Table 6: $\quad$ The impact of $\mathbf{2 0 \%}$ increase in export of machinery and equipment n.e.c. in Germany

\begin{tabular}{|l|r|}
\hline \multicolumn{1}{|c|}{ Sector } & \multicolumn{1}{|c|}{ Output } \\
\hline Machinery and equipment n.e.c. & $18.62 \%$ \\
\hline Fabricated metal products, except machinery and equipment & $2.76 \%$ \\
\hline Employment services & $2.19 \%$ \\
\hline Basic metals & $2.03 \%$ \\
\hline Repair and installation services of machinery and equipment & $1.72 \%$ \\
\hline Rubber and plastics products & $1.23 \%$ \\
\hline Warehousing and support services for transportation & $1.09 \%$ \\
\hline $\begin{array}{l}\text { Legal and accounting services; services of head offices; management consulting } \\
\text { services }\end{array}$ & $1.05 \%$ \\
\hline Wholesale trade services, except of motor vehicles and motorcycles & $0.92 \%$ \\
\hline Electrical equipment & $0.88 \%$ \\
\hline
\end{tabular}

Unlike the previous two sectors, an increase in export of the German automotive sector is expected to have a significant impact on job creation in the three manufacturing sectors, namely the automotive sector, the fabricated metal products sector, and the rubber and plastics products sector. In total, a twenty percent increase in export of the automotive sector will create 378,479 new jobs. In another simulation, a 20 percent increase in export of the pharmaceutical sector is expected to create 54,176 new jobs. It is significantly smaller than other simulations. Lastly, a 20 percent increase in export of the machinery sector is expected to create 359,154 new jobs. However we should be cautious to compare the results of those four simulations. In the simulation we use 20 percent of current export as the shock. Thus, 20 percent increase in export of the automotive sector (31,523 million Euros) is significantly larger than 20 percent increase in export of the pharmaceutical sector (5,767 million Euros).

To sum up, the results of five simulations which are presented in Appendix 5 suggest that the wholesale and retail trade sector and several services sectors are expected to experience a relatively significant positive impact if any of those five sector experiences higher export. The magnitude of the impact does not depend solely on the linkage between the four observed sectors but also depends on the character of the sector itself (whether the sector is a labor-intensive or capital intensive sector).

Finally, Appendix 6 shows the impact of TTIP on German sectoral output and employment. In this simulation we use the estimation of Felbermayr et al. (2013) as the shock in our IO multiplier matrix. Based on Felbermayr et al. (2013) estimation, the export of the chemical sector, the petrochemical sector, the automotive sector and the machinery sector is estimated to increase by 0.92 percent, 0.92 percent, 1.65 percent and 0.82 percent respectively. Meanwhile, the export of the ICT manufacturing sector is estimated to decrease (- 0.35 percent). The detailed 
estimation can be seen in Felbermayr et al. (2013) page 115. The export growth considered by Felbermayr et al. (2013) is rather modest.

Table 7 shows the impact of TTIP on the output and employment of German selected sectors. The automotive sector is expected to receive the largest positive impact among the sectors observed in terms of output and employment. In fact, the automotive sector is expected to experience the largest impact (both in terms of output and employment) relative to other sectors in German economy. The output of the automotive sector is expected to increase by 1.60 percent. Moreover, the total number of new jobs that are created in this sector is estimated to be as high as 13,262 which is equal to 37 percent of total new jobs created in all sectors due to TTIP agreement.

Table 7: $\quad$ The impact of an increase in exports due to TTIP agreement on German sectoral output and labor (selected sector); implications of export growth based on Felbermayr et al. (2013)

\begin{tabular}{|l|r|r|}
\hline \multicolumn{1}{|c|}{ Sector } & $\begin{array}{c}\Delta \\
\text { Output }\end{array}$ & \multicolumn{1}{c|}{$\begin{array}{c}\Delta \\
\text { Labor }\end{array}$} \\
\hline Chemicals and chemical products & $0.84 \%$ & 2,805 \\
\hline Computer, electronic and optical products & $-0.17 \%$ & -676 \\
\hline Motor vehicles, trailers and semi-trailers & $1.60 \%$ & 13,262 \\
\hline Basic pharmaceutical products and pharmaceutical preparations & $0.88 \%$ & 1,100 \\
\hline Machinery and equipment n.e.c. $^{\text {(a) }}$ & $0.80 \%$ & 8,308 \\
\hline Total (all sector) $^{\text {b) }}$ & $0.23 \%$ & 35,971 \\
\hline
\end{tabular}

Note: ${ }^{b)}$ Important to note that changes in output for all sector is not equal to changes in GDP since IO analysis is subject to multiple counting

Three other observed sectors, namely the automotive sector, pharmaceutical sector and the machinery sector are also experiencing positive impact. Output will increase by 0.84 percent, 0.88 percent and 0.80 percent respectively. Even though the impact on those three sectors is small in magnitude, those three sectors are among the top ten most affected sectors. In terms of sectoral employment, an increase in sectoral export due to TTIP will create 2,805 new jobs in the chemical sector, 1,100 new jobs in the pharmaceutical sector, and 8,308 new jobs in the machinery sector. In contrast, the ICT manufacturing sector is expected to experience a slowdown in its output by as much as 1.60 percent. It is also predicted that about 676 people in the ICT manufacturing sector will lose their jobs.

Up to this point, we have underlined several aspects that will determine the magnitude of the impact of TTIP on German sectoral output and employment. The first aspect is the proportion of the imported intermediate inputs which is used by the sector. If the sector has a large proportion of imported intermediate input, some of the positive impact of TTIP will benefit other countries which produced intermediate inputs for the sector. The second aspect is the linkage between sectors in the economy. If the sector that experiences a significant increase in export due to TTIP has a strong linkage with other important sectors in the economy, the aggregate impact is 
expected to be significant. Lastly, the character of the sector itself will also determine the magnitude of the impact, particularly if we focus on the impact on employment. Therefore, we should also consider trade in value added statistics instead of only using the conventional trade statistic (gross trade).

Figure 7: $\quad$ Export of Germany to the US (Selected sectors)

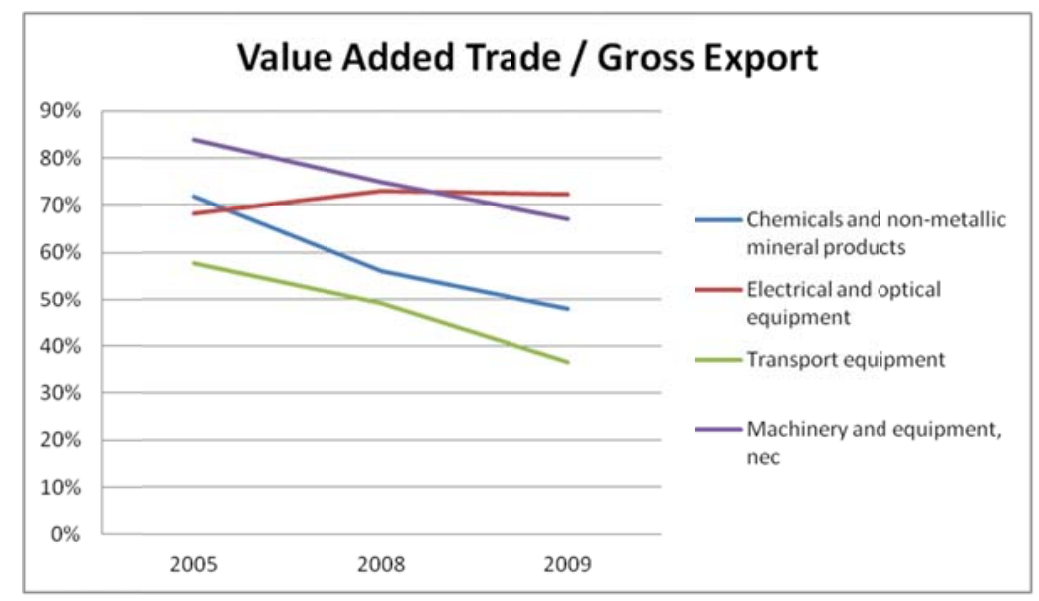

Source: OECD-WTO TiVA Database

Since 2012 the OECD and WTO have published the Trade in Value Added Database which is known as the TiVA Database. By using the TiVA database we will be able to calculate the "real" value of export of a particular country to other countries. In other words, it is also known as domestic value added which is embedded in the gross export. Important to note that sector classification which is used in the TiVA database is not similar with the one which is used in an IO Table. We cannot convert sector classification in the TiVA database into NACE Rev. 2 due to data limitation. Nevertheless, we still can get valuable information from four sectors in the TiVA database, namely the chemicals and non-metallic mineral products sector, the electrical and optical equipment sector, the transport equipment sector and the machinery and equipment n.e.c. sector. The chemical sector and pharmaceutical sector is part of the chemicals and non-metallic mineral products sector. The ICT manufacturing sector is part of the electrical and optical equipment. Lastly, the automotive sector is part of transport equipment.

Figure 7 shows the dynamic of the value added trade relative to gross export of German export to the US. In general, three out of four observed sectors have a negative trend during the observed periods. These imply that the imported intermediate inputs are getting more important in the production of the German products (4 sectors) which are exported abroad. Consequently, an increase in export of those 3 sectors will have smaller impact (in 2009 relative to 2005) on the German economy since some of the benefit (due to higher export) will be transmitted to other countries (where some of value added is created). 
Figure 8: $\quad$ Export of the US to Germany (Selected sectors)

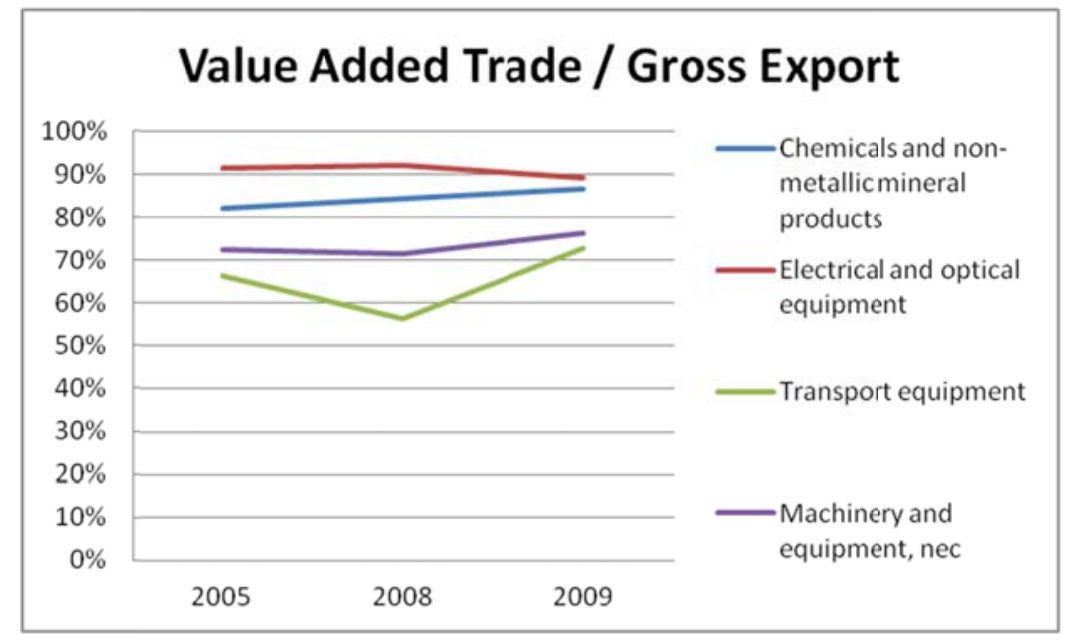

Source: OECD-WTO TiVA Database

Unlike Germany, all observed sectors in the US are quite stable in terms of the ratio of value added trade relative to gross export. Furthermore, there is a slight increase in the ratio of value added trade relative to gross export in three observed sectors, namely the chemical and nonmetallic mineral products sector, the transport equipment sector, and the machinery and equipment, n.e.c., sector. These imply that the positive impact of an increase in exports will be absorbed mostly by the US economy.

Table 8: $\quad$ Trade Balance between Germany and the US (selected sectors); millions of US \$

\begin{tabular}{|c|c|c|c|c|c|c|}
\hline \multirow{2}{*}{ Trade Balance } & \multicolumn{3}{|c|}{ Gross Trade } & \multicolumn{3}{|c|}{ Trade in Value Added } \\
\hline & 2005 & 2008 & 2009 & 2005 & 2008 & 2009 \\
\hline Chemicals \& non-metallic mineral pr. & 9666.2 & 6643.1 & 2269.9 & 5976.3 & -848 & -3873.9 \\
\hline Electrical \& optical equipment & -1435.7 & 1480.2 & 1329.8 & -3561.5 & -1716.1 & -855.2 \\
\hline Transport equipment & 5728 & 10910.9 & 5232.6 & 2589.8 & 4766 & -576.9 \\
\hline Machinery and equipment, n.e.c. & 14933.2 & 16758.2 & 10086.2 & 13036.2 & 12765.2 & 6391.5 \\
\hline
\end{tabular}

Source: OECD-WTO TiVA Database

Table 8 presents the comparison of trade balance which is calculated based on gross trade and trade in value added. Generally, based on gross trade, Germany has a surplus trade in all four sectors and all observed periods (except 2005 for the electrical and optical equipment sector) with its trading partner, the US. However, the picture will be completely different if we consider trade in value added. Germany has surplus trade balance only in one sector all observed period, i.e. the machinery and equipment n.e.c. sector. Moreover, it also suggests that the German surplus trade balance in the machinery and equipment n.e.c. sector has been diminishing over time. 


\section{Machinery \& Equipment Sector and FDI Perspectives}

There are some particular aspects of the sector machinery and equipment (n.e.c.) - and to some extent also for the ICT equipment sector:

* Part of the machinery and equipment sector, namely the production of highly specialized hightech machinery and equipment may be dubbed an immobile Schumpeterian sector (Klodt, 1992): It is rather technology intensive, but since production and $R \& D$ activities have to be in the same location this sector is not really footloose internationally so that production is rarely relocated across borders (it is not really clear how large the share of investment production in various OECD countries this is). This implies a special advantage for countries which have successfully specialized in machinery and equipment production - and particularly in this niche, one will face rather limited competition and Schumpeterian rents might be considerable.

* The international specialization in the production of machinery and equipment is rather distinct if one takes the share of the sector's output in GDP: Taking a look at the pre-crisis year 2007 the OECD country with the highest share of investment goods production (broadly defined) to GDP is the Republic of Korea which recorded a share of $18.1 \%$, followed by Germany, Japan, Sweden, Austria and Switzerland with 14.8\%, 11.6\%, 11.0\%, 10.6\% and 10.1\%, respectively. The shares of Italy, Spain, Belgium, Denmark, France, Ireland and the US reached 9.2\%, 6.3\%, $6.2 \%, 6.2 \%, 5.9 \%, 5.9 \%$ and $5.4 \%$, respectively (the figures for Luxembourg, the UK, the Netherlands, Portugal and Greece were 5.1\%, 5.0\%, 4.7\%, 4.0\% and 2.5\%, respectively; IWD (2013, p.3)). By this token Germany, Sweden and Austria are strongly specialized in the production of machinery and equipment in the EU, the share in US output is only about $1 / 3^{\text {rd }}$ of that in Germany. The sectoral trade balance in machinery and equipment relative to GDP was $10.8 \%$ in the Republic of Korea, $9.5 \%$ and $7.5 \%$ in Germany and Japan, respectively; the figures for Sweden, Austria and Switzerland were 2.8\%, 3.0\% and 2.6\%, respectively. The US had a sectoral current account deficit of $2 \%$ of GDP and this amounted to $1 / 2$ of the overall trade balance deficit and $2 / 5^{\text {ths }}$ of the current account deficit. Germany's transatlantic sectoral trade balance in machinery and equipment was quite large (Table 8) in 2005/08, it fell in 2009 in the aftermath of the US recession in 2008/09. This picture does not change much if we switch from gross trade figures to sectoral value added exports and imports: Germany has a large surplus visà-vis the US. We therefore expect particular gains in the US-bound export of this sector once a transatlantic trade and investment partnership has been established; there should also be secondary growth impulses for this important sector in Germany since TTIP-generated output growth in other EU countries also is poised to stimulate Germany's export in the sector of machinery and equipment.

* The share of machinery and equipment (n.e.c) in domestic intermediate inputs in this sector in Germany reached 20.3\% in 2009; this shows that a large part of intermediate input is from this very sector itself (it is noteworthy that in the EU the share of this sector as an intermediate domestic input source was also rather high in the EU, namely $17.1 \%$; see on these figures and the following data the set of statistics in the Appendix 4). Fabricated metal products and wholesale 
trade services reached $9.7 \%$ and $6.7 \%$ within the bloc of domestic intermediate inputs. Imported intermediate inputs of machinery and equipment (n.e.c) reached $9.4 \%$ for Germany. By contrast, the US machinery and equipment sector has a different intermediate input structure: On the domestic intermediate input side fabricated metal products reached $14.3 \%$, basic metals $11.5 \%$ and machinery and equipment (n.e.c) $9.4 \%$ which is just about $1 / 2$ of the respective share of the same sector in Germany. Imported intermediate inputs recorded a share of 3.3\% of basic metals and $2.9 \%$ for machinery and equipment in the case of the US. Germany's machinery and equipment sector thus is larger - relative to GDP - and it is relying more on intra-industry intermediate domestic inputs than the respective counterpart sector in the US. It seems that Germany's machinery and equipment sector is more important and more successful on the basis of this rather sophisticated supplier structure than its US counterpart. By contrast the US is a rather successful net exporter of electrical and optical equipment as the negative sectoral trade balance - based on value-added exports and imports - shows for 2005, 2008 and 2009.

Among the few Asian countries that clearly stand to benefit from TTIP is the Republic of Korea since it has concluded a Free Trade Agreement with both the US and the EU. Moreover, as the share of machinery production in Korea's GDP is so high and its sectoral trade balance surplus so big one may anticipate favorable sectoral trade creation effects between "USAEU” (US+EU) and Korea. To the extent that the information and communication technology sector and machinery \& equipment stand for ample opportunities for cross innovation, Korea, with its large ICT sector, might enjoy particular benefits in the long run. The composition of the FDI stock gives information about particular strengths of sectors.

The share of Germany's machinery and equipment sector's FDI stock in the US was $7.5 \%$ in 2011 and 6.8\% in 2012. The share of the US counterpart sector's FDI stock in Germany was lower: it reached $4 \%$ in both years. Non-electrical machinery is a rather immobile Schumpeterian industry so that only part of the machinery and equipment sector is internationally mobile. As regards Germany's FDI position in the US the share was $8.7 \%$ and $7.9 \%$ in chemicals in 2011/2012, in transportation equipment (motor vehicles etc.) it stood at $8.7 \%$ and $9.9 \%$; by contrast FDI in the sector computers and electronic products was 0.5 and $0.6 \%$, respectively this latter sector thus stands for a rather weak international position of a particular German industry. As regards the US FDI position in Germany this sector was rather strong since computers and electronic products stood for 3.5\% and 6.9\% in 2011 and 2012, respectively. US Transportation equipment recorded shares of $4.0 \%$ and $3.8 \%$, respectively; the US chemicals' share of FDI stock figures was $4 \%$ in both years in Germany. As NTBs and tariffs are expected to be reduced one may assume that transatlantic FDI will reduce transitorily since the incentive for tariff-jumping through FDI is weakened. However, in the long run transatlantic FDI is expected to increase for several reasons:

- In knowledge-intensive and technology-intensive industries the prospects for enhanced competition in technology-intensive industries reinforce the motivation for asset-seeking FDI. 
- Several industries are characterized by a rather oligopolistic structure so that reaction interdependence in FDI and mutual invasion headquarter countries and key markets may be expected.

- With the share of knowledge-intensive and technology-intensive sectors in total output expanding on both sides of the Atlantic one may expect more outward FDI that is reflecting ownership-specific advantages.

Judging the relative strength of a sector by the relative FDI share one may assume that Germany's automotive sector and machinery \& equipment sector are strongly positioned and thus these sectors could particularly generate benefits from TTIP for Germany's gross national income growth. Indeed, when it comes to economic welfare analysis one would not naturally look at gross domestic product, rather GNP has to be considered which includes the net international profits accruing from abroad. Since the ICT sector of the US is so strong in Germany (and the EU) one may argue that different sectors stand to benefit from TTIP on the basis of FDI: There are good prospects for US companies in the ICT sector to generate considerable profits through German/EU subsidiaries, Germany's strong points are the automotive and machinery \& equipment sectors and the chemicals sector stands for a potential winner on both sides of the Atlantic. If transatlantic exports of the US and Germany should increase one may anticipate that firms in the US will consider more international outsourcing and offshoring within NAFTA and German firms will focus on additional opportunities for (mainly) outsourcing and offshoring on an intra-EU basis. 
Table 9: $\quad$ US FDI Outward to Germany (in percent relative to total FDI)

\begin{tabular}{|l|l|l|l|l|l|l|l|l|l|l|l|l|l|l|}
\hline Sector & $\mathbf{1 9 9 9}$ & $\mathbf{2 0 0 0}$ & $\mathbf{2 0 0 1}$ & $\mathbf{2 0 0 2}$ & $\mathbf{2 0 0 3}$ & $\mathbf{2 0 0 4}$ & $\mathbf{2 0 0 5}$ & $\mathbf{2 0 0 6}$ & $\mathbf{2 0 0 7}$ & $\mathbf{2 0 0 8}$ & $\mathbf{2 0 0 9}$ & $\mathbf{2 0 1 0}$ & $\mathbf{2 0 1 1}$ & $\mathbf{2 0 1 2}$ \\
\hline \multicolumn{1}{|c|}{ TOTAL } & $100 \%$ & $100 \%$ & $100 \%$ & $100 \%$ & $100 \%$ & $100 \%$ & $100 \%$ & $100 \%$ & $100 \%$ & $100 \%$ & $100 \%$ & $100 \%$ & $100 \%$ & $100 \%$ \\
\hline $\begin{array}{l}\text { Total } \\
\text { Manufacturing }\end{array}$ & $50.6 \%$ & $52.7 \%$ & $33.6 \%$ & $27.0 \%$ & $23.3 \%$ & $27.0 \%$ & $22.8 \%$ & $29.4 \%$ & $28.2 \%$ & $23.2 \%$ & $26.2 \%$ & $24.5 \%$ & $24.8 \%$ & $29.0 \%$ \\
\hline Chemicals & $5.5 \%$ & $3.7 \%$ & $9.9 \%$ & $3.8 \%$ & $3.9 \%$ & $3.6 \%$ & $3.7 \%$ & $5.0 \%$ & $6.2 \%$ & $5.8 \%$ & $6.2 \%$ & $3.7 \%$ & $4.0 \%$ & $4.0 \%$ \\
\hline Machinery & $3.3 \%$ & $3.4 \%$ & $2.0 \%$ & $2.2 \%$ & $1.5 \%$ & $2.8 \%$ & $2.3 \%$ & $2.7 \%$ & $3.2 \%$ & $3.1 \%$ & $3.1 \%$ & $3.5 \%$ & $4.1 \%$ & $4.1 \%$ \\
\hline $\begin{array}{l}\text { Computers and } \\
\text { Electronic } \\
\text { Products }\end{array}$ & $8.1 \%$ & $10.7 \%$ & $4.2 \%$ & $3.6 \%$ & $4.0 \%$ & $4.1 \%$ & $4.6 \%$ & $4.0 \%$ & $3.6 \%$ & $3.6 \%$ & $4.8 \%$ & $5.0 \%$ & $3.5 \%$ & $6.9 \%$ \\
\hline $\begin{array}{l}\text { Transportation } \\
\text { Equipment }\end{array}$ & $22.1 \%$ & $19.7 \%$ & $7.1 \%$ & $6.7 \%$ & $5.2 \%$ & $5.4 \%$ & $3.8 \%$ & $7.7 \%$ & $7.2 \%$ & $0.9 \%$ & $4.4 \%$ & $3.4 \%$ & $4.0 \%$ & $3.8 \%$ \\
\hline
\end{tabular}

Source: BEA United States

Table 10: $\quad$ US FDI Inward from Germany (in percent relative to total FDI)

\begin{tabular}{|c|c|c|c|c|c|c|c|c|c|c|c|c|c|c|}
\hline Sector & 1999 & 2000 & 2001 & 2002 & 2003 & 2004 & 2005 & 2006 & 2007 & 2008 & 2009 & 2010 & 2011 & 2012 \\
\hline TOTAL & $100 \%$ & $100 \%$ & $100 \%$ & $100 \%$ & $100 \%$ & $100 \%$ & $100 \%$ & $100 \%$ & $100 \%$ & $100 \%$ & $100 \%$ & $100 \%$ & $100 \%$ & $100 \%$ \\
\hline $\begin{array}{l}\text { Total } \\
\text { Manufacturing }\end{array}$ & $49.3 \%$ & $48.3 \%$ & $34.9 \%$ & $37.0 \%$ & $33.1 \%$ & $33.9 \%$ & $37.4 \%$ & $32.1 \%$ & $28.8 \%$ & $30.5 \%$ & $28.8 \%$ & $32.6 \%$ & $33.8 \%$ & $33.9 \%$ \\
\hline Chemicals & $16.5 \%$ & $14.5 \%$ & $11.7 \%$ & $12.9 \%$ & $12.2 \%$ & $12.8 \%$ & $14.2 \%$ & $12.8 \%$ & $11.4 \%$ & $13.1 \%$ & $13.0 \%$ & $11.1 \%$ & $8.7 \%$ & $7.9 \%$ \\
\hline Machinery & $2.6 \%$ & $2.4 \%$ & $5.4 \%$ & $4.9 \%$ & $3.4 \%$ & $3.7 \%$ & (D) & (D) & $4.8 \%$ & $4.8 \%$ & $4.9 \%$ & $4.4 \%$ & $7.5 \%$ & $6.8 \%$ \\
\hline $\begin{array}{l}\text { Computers and } \\
\text { Electronic } \\
\text { Products }\end{array}$ & $0.6 \%$ & $0.4 \%$ & $0.3 \%$ & $0.6 \%$ & $0.4 \%$ & $0.3 \%$ & $0.4 \%$ & $0.4 \%$ & $0.4 \%$ & $0.4 \%$ & $0.4 \%$ & $0.6 \%$ & $0.5 \%$ & $0.6 \%$ \\
\hline $\begin{array}{l}\text { Transportation } \\
\text { Equipment }\end{array}$ & $21.8 \%$ & (D) & $11.8 \%$ & $12.0 \%$ & $11.0 \%$ & $11.9 \%$ & $12.1 \%$ & $8.4 \%$ & $7.7 \%$ & $7.0 \%$ & $5.8 \%$ & $9.1 \%$ & $8.7 \%$ & $9.9 \%$ \\
\hline
\end{tabular}

Source: BEA United States

(D) --> indicates that the data in the cell have been suppressed to avoid disclosure of data of individual companies. 
A special aspect of TTIP is associated with the development of the transatlantic current account position and capital flows, respectively. In a world of imperfect capital markets a real appreciation of the currency will lead to higher FDI inflows as foreign bidders will have more equity capital - expressed in terms of the target country; Froot and Stein (1991) have presented empirical evidence for such an approach for the US. Klein and Rosengren (1992) have presented evidence that US FDI outflows depend on relative wealth - read: US wealth divided by the wealth position of the target country - and on relative wages; the relative wealth position which is influenced by the exchange rate has an impact on US FDI outflows because a relatively improved wealth position (after an appreciation of the US \$) implies that US firms are less wealth constrained when bidding for foreign companies. While new studies have shed additional light on FDI dynamics in the US (Krugman and Graham, 1995) and Europe (e.g. Brenton et al. (1998)) the role of relative wealth remains crucial. If fear of trade diversion effects of TTIP would stimulate FDI outflows from Asian countries and other Newly Industrialized Countries to both the US and the EU one may anticipate both an appreciation of the $\$$ and the $€$ vis-à-vis other currencies and hence the medium term side effect of TTIP would be a rise of US FDI outflows and EU FDI outflows to certain Asian and Latin American countries. To the extent that FDI inflows generate international technology spillovers, countries in Asia and Latin America should record medium term benefits from TTIP even if there are short-term trade diversion effects.

How will the real exchange rate $(\mathrm{eP} * / \mathrm{P})$ and the nominal exchange rate e develop over time? This question largely refers to the $€ / \$$ exchange rate and the British Pound/\$ exchange rate; there is no reason to assume that the transatlantic price ratio $\mathrm{P} * / \mathrm{P}$ would change strongly in the short term as monetary policy in both the US and the euro area, as well as the UK, are not expected to be affected by TTIP. From a theoretical perspective one may look at a simple Branson portfolio model (Branson, 1977) with money (M), domestic bonds (B) and foreign bonds $\mathrm{F}^{*}$ (denominated in foreign currency); strictly speaking this model is for a small open economy under flexible exchange rates, but it is nevertheless a useful point of reference - certainly if we think about the UK relative to the US. Denoting real wealth as $A^{\prime}:=M / P+B / P+\mathrm{eF}^{*} / \mathrm{P}$ and assuming that the desired shares $h, b$ and $f$ are proportionate to real wealth (e.g. the demand for money is $h\left(i, i^{*}\right) A^{\prime}$ and hence the equilibrium condition for the money market is $\mathrm{M} / \mathrm{P}=\mathrm{h}\left(\mathrm{i}, \mathrm{i}^{*}\right) \mathrm{A}^{\prime}$ where $\mathrm{P}$ is the price level and $\mathrm{i}$ the nominal interest rate; * denotes foreign variable) we get from considering the equilibrium condition for the foreign bonds market, namely $\mathrm{FF}^{*} / \mathrm{P}=\mathrm{f}\left(\mathrm{i}, \mathrm{i}^{*}\right) \mathrm{A}^{\prime}$ the following expression for the exchange rate (assuming the simple specification $f\left(i, i^{*}\right)=\lambda i^{*} / i$; here $\lambda$ is a positive parameter and $0<\mathrm{f}<1$ ):

$$
\mathrm{e}=\left(\lambda \mathrm{i}^{*} / \mathrm{i}\right)(\mathrm{B} / \mathrm{P}+\mathrm{M} / \mathrm{P}) /\left[\left(1-\left(\lambda \mathrm{i}^{*} / \mathrm{i}\right)\right)\left(\mathrm{F}^{*} / \mathrm{P}\right)\right] .
$$

Hence a current account surplus which raises $\mathrm{F}^{*}$ will bring about an appreciation and thus one could raise the question of how TTIP will affect the current account balance. Alternatively, one could express de/dt (t for time index) to be a positive result from the excess demand for the foreign bonds market or one could consider a system of two asset markets - and the respective equilibrium conditions - plus the budget constraint. Since the shares in the three assets add up to 1 only two markets are independent. 
The bilateral current account position of the euro area vis-à-vis the US is positive and if TTIP reinforces this we will see a short-term appreciation of the euro; with given price levels in the euro area and the US we have a real appreciation of the euro which will dampen the current account surplus of the euro area. In line with the Froot-Stein argument it holds that a real appreciation of the euro will stimulate FDI outflows from the euro area to the US. Looking at a medium term perspective of the exchange rate - and disregarding a broad modelling analysis one may consider a setting with two-way foreign direct investment flows: Net FDI inflows are assumed to be proportionate to the ratio of the marginal product of capital in the home country (euro area) to the marginal product abroad (US); and for simplicity this is the only type of international capital flows considered here. Assuming that both countries produce with capital K, knowledge $A$ and labor $\mathrm{L}$, namely according to $\mathrm{Y}=\mathrm{K}^{\mathrm{\beta}}(\mathrm{AL})^{1-\beta}$ and abroad according to $\mathrm{Y}^{*}=\mathrm{K}^{* \beta^{*}}\left(\mathrm{~A}^{*} \mathrm{~L}^{*}\right)^{1-\beta^{*}}$, we can state on the basis of an import function $\mathrm{J}=\mathrm{jY} / \mathrm{q}^{*}$ and an export function $\mathrm{X}=\mathrm{xY}^{*} \mathrm{q}^{*}$ the equilibrium condition for the foreign exchange market $\left(\mathrm{q}^{*}:=\mathrm{eP} / \mathrm{P}\right.$; $\mathrm{Y}$ is GDP; $\lambda^{\prime}>0 ; 0<ß<1 ; j>0, x>0$; denotes foreign variables):

$$
\lambda^{\prime}(ß Y / \mathrm{K}) /\left(ß^{*} \mathrm{Y}^{*} / \mathrm{K}^{*}\right)=\mathrm{jY} /\left(\mathrm{xY} \mathrm{q}^{*}\right)
$$

For the sake of simplicity the elasticity of imports with respect to the real exchange rate has been assumed to be -1 and that of exports with respect to $\mathrm{q}^{*}$ is +1 so that the Marshall Lerner condition is fulfilled. Note that real imports in domestic goods units are $q^{*} \mathrm{~J}=\mathrm{jY}$; however, a more refined approach would consider that exports in a world with FDI are not a function of gross domestic product Y but of gross national income $\mathrm{Z}$ (Welfens, 2011; if $\alpha$ denotes the share of capital owned by foreign investors we can write in a setup with competitive markets $Z=Y(1$ $\alpha * ß)+\alpha \beta^{*} Y^{*} q^{*}$ and $Z^{*}=Y^{*}\left(1-\alpha \beta^{*}\right)+\alpha^{*} \beta Y / q^{*}$. The result that we get in the simple setting is as follows for $\mathrm{q}^{*}$ :

(3) $\mathrm{q}^{*}:=\left[\mathrm{j} ß *\left(K / \mathrm{K}^{*}\right) /\left(\lambda^{\prime} \mathrm{x} ß\right)\right]$

If TTIP brings about a rise of $\lambda$ ' so that foreign investors react more strongly to transatlantic differences in the marginal product of capital there will be a real depreciation of the currency and this also holds if $\AA^{*} / \S$ or $K / K^{*}$ is rising. Note that we can replace $K / K^{*}$ by $\left(k^{\prime} / k^{*}\right)(A L) /\left(A^{*} L^{*}\right)$ with $\mathrm{k}^{\prime}:=\mathrm{K} /(\mathrm{AL})$ - and $\mathrm{k}^{\prime}$ and $\mathrm{k}^{*}$ could be determined within an international neoclassical growth model; let us recall (with $\tau$ denoting the income tax rate): if savings $S=s(1-\tau) Y$ and the growth rate of the population is $\mathrm{n}$, the growth rate of knowledge is a and the rate of capital depreciation is $\delta$ we obtain in a closed economy for the steady state value $\mathrm{k}^{\prime} \#:=$ (s(1$\tau) /(a+n+\delta))^{1 /(1-\beta)}$. In this perspective one has to raise the question of whether or not TTIP will affect the savings rate and the income tax rate in the EU or the US and to what extent the progress rates a and $\mathrm{a}^{*}$ will change; adequate endogenous growth approaches could be useful here and with FDI increasing relative to GDP the size of international technology spillovers are expected to increase. An interesting perspective is raised by considering a simple endogenous modelling of total factor productivity growth (Welfens, 2014): Assume that we have the following specification (with $\mathrm{j}$ ' denoting the share of imported intermediates $\mathrm{J}$ ' relative to $\mathrm{Y}, \mathrm{x}$ is the share of exported goods relative to $\mathrm{X}$ and $\alpha$ is the share of capital ownership of foreign investors in country I (home country), $s$ ' is a measure of intra-industrial trade intensity (Grubel- 
Lloyd index); j”, $x^{\prime}, \alpha^{\prime}, \alpha^{*}$ and $\mathrm{s}^{\prime}$ are positive parameters and $\mathrm{a}_{0}$ is the exogenous progress rate):

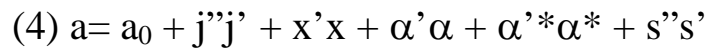

The idea behind that equation is that intermediate imports will contain embodied knowledge and this is indeed a crucial aspect for trade expansion between leading OECD countries. A rise of $\mathrm{x}$ in turn requires increasing specialization in combination with more product differentiation that in turn goes along with a higher rate of technological progress. The higher the share of foreign investors in the capital stock, the more international technology transfer takes place through cumulated FDI inflows. The higher the share of capital owned abroad the larger the opportunity for positive technology spillovers in the foreign host country - subsidiaries will benefit from intra-sectoral or cross-sectoral technology spillovers abroad and part of the new knowledge will be transferred to the country in which the parent company is located. A higher intensity of intraindustrial trade generates pressure for firms to embark in increasingly technological and knowledge-intensive production and thus to contribute to a higher aggregate rate of technological progress.

The progress rate thus has been decomposed in exogenous right-hand side elements and taking this into account in $y^{\prime} \#:=(s(1-\tau) /(a+n+\delta))^{\beta /(1-\beta)}$ implies that a rise of a in the steady state at a point of time t' implies a short-term fall of the level of the growth rate and per capita income $y$ (and of y') and a permanent increase of the growth rate of y' and y, respectively. TTIP could raise the share of foreign ownership in the capital stock in both the EU (rise of $\alpha$ ) and in the US (rise of $\alpha^{*}$ ) and j', $x$ and s' are also likely to increase in the EU. An analogous equation can be stated for the foreign country (read the US).

It is interesting to focus on the impact of TTIP on foreign direct investment. As Barrell/Pain (1997) have shown for FDI of Germany and the UK, knowledge-based assets of the host country - read: patents - play a positive role for foreign direct investment; moreover, the GDP of the host country and the relative low-cost position have a positive impact. To the extent that TTIP stimulates innovation dynamics in the EU we thus should expect higher FDI inflows in Europe (and in the USA, too). Barrell/Pain emphasize that the EU single market program has raised intra-EU FDI by about $0.5 \%$ of GDP; moreover, their analysis shows that a $1 \%$ rise of the FDI stock in the manufacturing sector raises the rate of technological progress by $0.26 \%$ in the UK and by $0.27 \%$ in Germany - by contrast FDI inflows in non-manufacturing in the UK had no effect on technological progress. Finally, Barrel/Pain show that export demand of the UK, Germany, France and Sweden are negatively affected by net outward FDI stocks: the elasticity is rather even across countries and is close to $-0.15 \%$. Export demand is positively affected by the relative patent position of domestic producers relative to the weighted average of competitors' patents. The FDI dynamics of TTIP thus deserve more attention in future research.

One should not rule out that the savings rate in both the US and the EU will fall in a more integrated transatlantic financial market so that the level of the growth path could fall, however, one will also have to analyse whether or not the availability of risk capital for relatively technology intensive sectors - such as pharmaceuticals, chemicals, automotive, ICT and machinery \& equipment - will improve in Europe. 
As regards the employment effect of a $20 \%$ increase of exports in the five sectors considered, the Appendix 5 shows for Germany an increase in the chemicals sector of 129000 - of which 55 000 are in the chemicals sector itself; a rise of the number of jobs in the ICT producing sector of 116000 - of which 65000 are in the ICT sector itself; a rise of 378000 in the automotive sector - of which 160000 are in that sector itself; a rise of 54000 in the pharmaceuticals sector of which 24000 are in that sector itself; and a rise of 359000 jobs in the sector machinery and equipment (n.e.c.) of which 194000 are in that sector itself. This adds up to an impressive sum of 836000 which would reduce Germany's unemployment figure from about 3 million in 2013 to about 2 million, roughly the equivalent of full employment. However, there are three caveats with this figure: (i) if imports in these sectors should also strongly increase it could happen that the net employment effect is indeed smaller. (ii) the number 836000 could be achieved within a decade or so and this implies that the annual increase of jobs will be less impressive. (iii) if the plus of 836000 largely represents an increase in the demand of skilled labor the rising demand for skilled workers could considerably raise the real wage of skilled workers. Moreover, there could be a real appreciation and this could dampen net exports of goods and services and employment growth, respectively. As regards aggregate employment effects it should be emphasized that only broader macroeconomic modelling can shed a true spotlight on the employment effects.

As regards the Schumpeterian innovation dynamics one may point out that input output analysis shows that the share of research services imported is very small in intermediate supplies (see Appendix 12). Only defense and education show imported scientific services to a considerable extent, while human health services stand for some minor imports. As regards domestic scientific services as inputs only a few sectors are relevant in Germany, the EU and the US; so much R\&D is in-house. 


\section{Policy Issues}

TTIP will not only concern trade, but will also address the issue of protectionism behind borders, for example the rules of origin, subsidies, regulations, government procurement and the role of state-owned enterprises. However, there also is a broader issue which is partly related to trade but also to the field of investment protection which will also be part of TTIP. The legal standards and approaches in the US differ considerably from European traditions and it will be quite interesting to which extent the transatlantic market will be more determined by US legal approaches or by EU legal standards. From the input output analysis for US sectors (see Appendix 2) one can take an important fact: Legal services plus controlling represents in all US sectors - with the exception of machinery \& equipment (n.e.c) - a considerable activity among the domestic intermediate inputs; by contrast in none of the EU sectors does this activity play a major role. While we cannot make a simple split between legal services and controlling services one may state the hypothesis that the figures indicate that in the US institutional framework legal services play a much larger role than in Germany and the EU, respectively. Hence if in the future - within the context of TTIP - the US institutional framework would effectively become increasingly applied in Europe one may anticipate additional costs for European firms and new business opportunities in Europe for leading US law firms. This is a point that EU negotiators should carefully take into consideration and given the different legal approaches on both sides of the Atlantic it could be difficult to formulate a consistent compromise.

Assuming that TTIP will mainly stimulate the expansion of technology-intensive and knowledge-intensive sectors in the US and the EU it is clear that the optimization of schooling, vocational training and education should be high on the agenda of national policymakers. Here many continental EU countries face the problem that almost all universities are in the hands of government and the political system - and this is favoring populist solutions and institutional arrangements; for example in Germany since 2013 the previous introduction of annual tuition fees of up to $€ 1000$ in public universities in several states was dropped and this is likely to lengthen the number years needed to complete a degree and it also undermines prospects of putting more resources into the education sector in a period in which the share of skilled labor should be increased in an efficient way. Countries with a mixture of private and public universities - such as the USA or Australia - seem to be better positioned to respond on the labor supply side to the challenges of ongoing economic globalization.

For Germany there will be a considerable challenge in the field of skilled labor since the simulations have shown a strong increase of new jobs in all sectors considered; the only sectors in which unskilled workers also play some role are the chemical industry and the automotive industry; moreover, one may assume that enhanced transatlantic competition in an integrated transatlantic market will encourage firms in Germany to engage more in international outsourcing and offshoring with the EU and this will reduce the demand for unskilled labor and raise the demand for skilled labor in Germany (in this respect TTIP labor market dynamics should be similar to those observed in the context of the creation of the EU single market). This 
view is much in contrast with IFO (2013) where the authors argue that in the context of TTIP wages of unskilled workers will increase more than wages of skilled workers in Germany.

In a more competitive transatlantic market innovation dynamics will play an increasing role and thus the optimization of innovation systems in Europe and the US could come on to the political agenda. In the EU there is - compared to the US - not only a problem with respect to a sufficient availability of risk capital. Several EU countries have also been suffering from a lack of FDI inflows over many years, for example FDI inflows into Italy, Spain, Portugal, Greece and several eastern European EU countries have been rather low. Given the fact that TTIP will bring temporary trade diversion at the expense of firms in Asia, Africa and Latin America one may anticipate that the EU and the US will benefit from rising FDI inflows: i.e. foreign investors from Asia will increasingly use FDI in the EU and in the US as a means of jumping over tariffs or non-tariff barriers. If such inflows from third countries should be very asymmetric and generate benefits mainly in northern EU countries there could be a rising economic divergence within the EU. The current Europe 2020 agenda of the European Commission has focused on raising R\&D expenditures relative to GDP and on progress in the field of environmental sustainability. However, key aspects of a more intensified quest for mobile capital and global FDI, respectively, have not been considered so far.

A key problem in the field of investment protection could occur once new rules are implemented that give firms broader opportunities to take governments to court for normal government action. Vattenfall, a Swedish energy multinational operating in many EU countries, has taken the German government to court over the energy U-turn of the German government - along with the German Parliament - after the Fukushima accident, in an attempt to claim $€ 3.7$ bill. in compensation from the government as Vattenfall's nuclear power plants will have to stop energy production by the end of 2022 at the latest; this court case has emerged in the context of the European Energy Charter which gives investor protection to European companies. There is not much doubt that MNCs from the US and Europe will push for favorable investor protection rules under TTIP. International investment treaties were mainly implemented in relations with developing countries whose legal systems seemed to be rather weak or not very reliable. Here, in the 1960s and 1970s, European countries often pushed for such treaties and later the US followed along the same lines. Dispute panels are likely to be adopted for cases of conflict in investor protection and it is not really clear that such out-of-court jurisdiction will be transparent and fair.

Since the ICT sector is of key importance for innovation dynamics and economic growth, respectively, one may argue that governments in the US and the EU will have an incentive to stimulate digital dynamics even more strongly than in previous decades. Part of the economic policy impulse comes from regulation of telecommunications. The digital communication market is the most obvious market that is truly global and one might at least consider some form of transatlantic joint regulation. In this respect the EU is at a disadvantage since despite the opening up of telecommunications markets in 1998 the interaction of supranational framework regulation and national regulations has generated only limited success: Prices have fallen, innovation dynamics have increased, but market consolidation in the EU has made rather modest progress. There was only one true merger after the opening up of fixed line telecommunication markets and partial privatization, namely the Swedish Telia taking over Sonera from Finland. The 
number of telecommunication companies in the EU largely exceeds that in the US and one may anticipate that US investors will take over part of the telecommunications operators in the EU once TTIP has been implemented. In a more competitive and larger transatlantic market the minimum optimum plant size is likely to increase in several sectors and in this perspective the incomplete digital regulatory framework in the EU stands for a political challenge; i.e. there should be common rules in all EU countries about the auctioning of telecommunications licenses, including options to sell such licenses in secondary markets - here there is a field where a common transatlantic policy approach would be useful. If more competition and a more efficient exploitation of static and dynamic scale economies would help to further bring down international telecommunication prices one may expect a rise of trade: Jungmittag and Welfens (2009) have presented empirical evidence that a fall of international telecommunication prices and rising international telecommunications calls, respectively, raise the volume of international trade as a consequence of declining international information costs. Thus regulatory policy in telecommunications is an example where TTIP could stimulate the modernization of regulatory policies and indeed a joint transatlantic approach in digital regulation - this in turn could then reinforce transatlantic and global trade and thereby reinforce the benefits from TTIP.

A key challenge for Germany - and some other EU countries - concerns high electricity prices compared to the US. With innovative fracking technology, in the US the production of gas has increased and this has contributed to a widening transatlantic gap in electricity prices. In a fully integrated transatlantic market the implication is that the US will be able to increasingly attract FDI in energy-intensive industries, for example in the chemicals sector where the direct use of natural gas is also important for certain products. As regards Germany the relative rise of electricity prices is partly reflecting policy effects; for example the generous feed-in tariffs offered for producers of renewable energy by the German government translate into a top-up on both household and industrial electricity prices - with many exceptions for big companies in the tradables sector. Those exceptions are considered by the European Commission as disguised distorting subsidies; this view is convincing in the EU single market on the one hand, on the other hand the single biggest implicit energy subsidy in France, the UK, Spain, the Netherlands, Belgium and Germany is the miniscule insurance coverage of nuclear power stations - in Germany plants have to get a minimum coverage of $€ 2.5$ billion which is less than $1 / 200^{\text {th }}$ of the amount of damage expected from a major accident in nuclear power generation. This caveat also applies, of course, to US nuclear power stations. A favorable side-effect of TTIP would be that EU countries would benefit from US gas exports that are banned unless the importing country is in a free trade area with the US.

Another TTIP challenge considers the application of ILO labor standards. A recent ILO study (Häberli et al., 2012) has shown empirical evidence that regional integration among industrialized countries tends to undermine the application of ILO core labor standards. If these findings are considered as relevant in the context of TTIP the European Commission and governments of EU countries and the US - possibly also of Canada and Mexico - should adopt rules that make sure that ILO labor standards are not undermined. It is not fully clear what drives the link between free trade areas (FTA) and a weakening of ILO standards. One possible explanation is that creation of FTA generates first round winners in the field of inward FDI 
inflows; the loser countries then have an incentive to water down the ILO standards as a means to attract higher FDI inflows in the second round.

China and other countries certainly are monitoring the transatlantic TTIP process. The solutions created in the context of a transatlantic free trade area could not only generate considerable benefits for Europe and the US but also encourage other FTAs to adopt similar solutions. Finally, as regards trade diversion effects the US could build on its Trans-Pacific Partnership initiative to reduce such effects strongly. The EU so far has no comparable undertaking linking Europe and Asia in a broader liberalization initiative. After the completion of negotiations of a rather straightforward FTA of the EU with Singapore in 2013 (Kutlina-Dimitrova and Lakatos, 2014) the EU has envisaged an FTA with Thailand. A superior approach could, however, be a broader approach that would aim directly at an FTA of the EU with ASEAN - or of the EU with the Mercosur which should be even simpler to achieve since the latter is a customs union just like the EU.

The sectoral analysis presented here lends itself to some complementary macroeconomic aspects and related policy issues. Since the sectors dealt with are crucial in terms of innovation dynamics, exports, FDI and employment - and since almost all sectors considered have considerable upstream and downstream linkages - the simulations presented shed additional light on the broader debate about TTIP. As regards current analytical contributions it is interesting to note that there are studies (commissioned by the authorities) for the UK, Sweden, the Czech Republic, France, Germany and the EU which all have been published, however, the study for the US Trade Representative has not been published. TTIP will also hopefully generate a common view that more public debate on the basis of relevant research is useful for a broader understanding of the issues and options; and will help avoiding policy pitfalls.

To sum up, we have many new useful insights from IO analysis. However, like many other quantitative analyses, IO analysis is also subject to several limitations. Firstly, IO analysis is static in nature. Thus it is not really appropriate to estimate the long-run impact. Secondly, IO analysis assumes that the technology is constant. Thirdly, IO analysis also assumes that the relationship between input and output is linear. Lastly, IO analysis cannot capture the impact of changes in prices over time. We suggest as a realistic version of the export simulations presented $2 / 3$ of the results so that the order of magnitude of new jobs expected is close to 0.5 million. A prudent version would be 10\% growth of Germany's export as a consequence of TTIP; in 2009 German exports to the US relative to Germany's global exports stood for $7 \%, 12 \%$ and $10 \%$ in the fields of the chemicals sector, pharmaceutical and the automotive sector, respectively figures are based on WITS database. Even if exports to the US would increase by $40 \%$ within a decade a high growth effect on intra-EU exports has to be realized if Germany's total exports were to increase by 20\%; if Germany's intra-EU exports stand for 50\% of total exports and the growth rate of those exports would have to be 30\%. As EU27 exports to the US indeed will increase as a consequence of TTIP Germany's exports to EU partner countries - partly in the field of intermediate products, partly in the form of final products (stimulated by higher imports as a consequence of higher real income in the EU) - the TTIP-induced growth of Germany's exports could be much higher than the trade growth effect for US-bound exports suggests. 
As regards sectoral employment effects one should be careful not to simply add up the sectoral employment gains in the context of higher exports; higher imports also should be considered in a broader perspective: a combination of IO analysis and macroeconomic modelling can be quite useful. As transatlantic competition will be enhanced in most sectors price convergence across countries will be reinforced and this in turn will generate efficiency gains and welfare gains, respectively.

As regards the prospects of TTIP negotiations a survey (Barker/Workman, 2013) found that the most difficult fields would be as follows: labor standards, environmental standards, investment liberalization, audio-visual quotas, geographic indicators, pharmaceutical testing, financial services, sanitary \& phyto-sanitary measures, regulations of manufactured goods, data protection/privacy, genetically modified organisms/agriculture and regulatory process convergence.

It is unclear to what extent more common regulation and mutual recognition will play a role within TTIP. While regulatory policies and issues of mutual recognition are rather complex fields for negotiators one could enhance competition dynamics and particularly the efficiency of capital markets by imposing on firms adequate standards for sustainability reporting. In this field EU firms seem to have some advantage, but some of those leading firms are indeed subsidiaries of US multinational companies; at the same time it should be considered that the Dodd-Frank Act requires US firms as of May 31, 2014, to disclose the whole supplier chain so that in principal one could get better information on the resource intensity, CO2 emissions and application of ILO labor standards along the whole chain of value-added. In a sectoral perspective input-output analysis can, of course, also be useful here; for example energyintensity and CO2-intensity of domestic and imported intermediate production could be analysed. The EU should consider adopting a parallel directive to the relevant chapters of the Dodd-Frank Act (the European Commission has already considered this policy field as potentially relevant: see European Commission, 2013: EU calls for Input on traded minerals). Multinational companies in the USAEU could thus become strong drivers not only of efficiency gains and new Schumpeterian innovation dynamics but could also stimulate more long term investment in line with sustainability. This implies new opportunities for global sustainability so that TTIP indeed could generate global positive external effects on a broad scale. TTIP thus could be a success story on many counts. The welfare gains could be significant if policy makers on both sides of the Atlantic adopt adequate and consistent initiatives so that TTIP in effect will become an element of global governance for a more integrated and sustainable world economy. Here further research is required and policy makers could strongly benefit indeed from new efforts here. 


\section{References:}

Barrell, R.; Pain, N. (1997), Foreign Direct Investment, Technological Change and Economic Growth within Europe, The Economic Journal, Vol. 107, 1770-1786.

Barker, T.; Workman, G. (2013), The Transatlantic Trade and Investment Partnership: Ambitious but Achievable, Atlantic Council \& Bertelsmann Foundation, Washington DC.

Bradford, S.C.; Lawrence, R.Z. (2004), Has Globalization Gone Far Enough? The Costs of Fragmented Markets, Washington DC: Institute for International Economics.

Branson, W.H. (1977), Asset Markets and Relative Prices in Exchange Rate Determination, Sozialwissenschaftliche Annalen 1, 69-89.

Brenton, P.; Di Mauro, F.; Liicke, M. (1998), Economic Integration and FDI: - An Empirical Analysis of Foreign Investment in the EU and in Central and Eastern Europe, Kiel Working Paper No. 890, Institute of World Economics.

CEA (Council of Economic Advisers,2010), Economic Report of the President, Washington DC.

Erixon, F.; Bauer, M. (2010), “A Transatlantic Zero Agreement, Estimating the Gains from Transatlantic Free Trade in Goods” ECIPE Occasional Paper 4/2010. Brussels: ECIPE.

Felbermayr, G.; Mario, L.; Lisandra, F.; Erdal, Y.; Sebastian, B. (2013), Dimensionen und Auswirkungen eines Freihandelsabkommens zwischen der EU und den USA, Study commissioned by German Federal Ministry of Economics and Technology, Munich.

Fontagné, L.; Gourdon, J.; Jean, S. (2013), Transatlantic Trade: Whither Partnership, Which Economic Consequences, Policy Brief CEPII, Paris.

Francois, J. et al. (2013), Reducing Transatlantic Barriers to Trade and Investment, London: CEPR (for the European Commission).

Froot, K.A.; Stein, J.C. (1991), Exchange rates and foreign direct investment: an imperfect capital markets approach. Quarterly Journal of Economics 106(4), 1191-1217.

Graham, E.M; Krugman, P.K. (1995), Foreign Direct Investment in the Unites States. Washington DC: Institute for International Economics.

Häberli, C.; Jansen, M.; Monteiro, J.A. (2012), Regional trade agreements and domestic labor market regulation, employment working paper No. 120, ILO, Geneva.

IFO (2013), Bundesländer, Branchen und Bildungsgruppen, Wirtschaftliche Folgen eines Transatlantischen Freihandelsabkommens (THIP) für Deutschland, Mikroökonomische Analyse (co-authored by Felbermayr, G.; Lehwald, S., Schoof, U.; Ronge, M.), Bertelsmann Foundation, Gütersloh.

IWD (2013), Investitionsgüter führen zu Überschüssen, iw-dienst, Ausgabe 15, Vol. 39, 3.

Jungmittag, A.; Welfens, P.J.J. (2009), Liberalization of EU telecommunications and trade: theory, gravity equation analysis and policy implications. International Economics and Economic Policy, Vol. 6, 23-39. 
Klein, M.; Rosengren E. (1992), Foreign Direct Investment Outflow from the United States: An Empirical Assessment, in: Klein, M.; Welfens, P.J.J., eds., Multinationals in the New Europe and Global Trade, Heidelberg and New York: Springer, 65-87.

Klodt, H. (1992), Technology-based Trade and Multinationals' Investment in Europe: Structural Change and Competition in Schumpeterian Goods, in: Klein, M.; Welfens, P.J.J., eds., Multinationals in the New Europe and Global Trade, Heidelberg and New York: Springer, 107-123.

Kutlina-Dimitrova, Z., Lakatos, C. (2013), Assessing the economic impacts of the EU-Singapore FTA with a dynamic general equilibrium model, International Economics and Economic Policy. DOI 10.1007/s10368-013-0262-7

Vernon, R. (1966), International Investment and International Trade in the Product Cycle, Quarterly Journal of Economics, Vol. 80, 190-207.

Welfens, P.J.J. (2011), Innovations in Macroeconomics, $3^{\text {rd }}$ revised and enlarged edition, Heidelberg and New York: Springer.

Welfens, P.J.J. (2013), Social Security and Economic Globalization, Heidelberg and New York: Springer.

Welfens, P.J.J. (2014), Technological Progress and Economic Growth in Open Economies: New Schumpeterian Perspectives, EIIW Working Paper No. 210, EIIW at the University of Wuppertal, forthcoming.

Welfens, P.J.J.; Perret, J. (2014), Information \& communication technology and true real GDP: economic analysis and findings for selected countries, International Economics and Economic Policy, DOI 10.1007/s10368-013-0261-8 (public access) 


\section{Appendix 1: Detailed consumption of intermediate inputs (observed}

\section{sectors in Germany) -Eurostat}

Chemicals and chemical products

\section{Domestic intermediate inputs}

Chemicals and chemical products

$$
\text { (16.8\%) }
$$

Wholesale and retail trade and repair services of motor vehicles and motorcycles (5.0\%)

Electricity, gas, steam and air-conditioning

$$
(4.1 \%)
$$

Coke and refined petroleum products (3.7\%)

Other domestic intermediate inputs (34.8\%)

\section{Imported intermediate inputs}

Chemicals and chemical products

$$
\text { (22.8\%) }
$$

Coke and refined petroleum products $(2.9 \%)$

Other imported intermediate inputs $(9.9 \%)$

Computer, electronic and optical products

\section{Domestic intermediate inputs}

Wholesale trade services, except of motor vehicles and motorcycles (11.6\%)

Computer, electronic \& optical products (9.8\%)

Retail trade services, except of motor vehicles and motorcycles (4.0\%)

Architectural and engineering services; technical testing and analysis services (3.3\%)

Other domestic intermediate inputs (42.0\%)

\section{Imported intermediate inputs}

Computer, electronic and optical products $(17.9 \%)$

Chemicals and chemical products (2.4\%)

Other imported intermediate inputs (9.0\%)
Motor vehicles, trailers and semi-trailers

\section{Domestic intermediate inputs}

Motor vehicles, trailers and semi-trailers sector $(28.1 \%)$

Wholesale and retail trade and repair services of motor vehicles and motorcycles (5.2\%)

Fabricated metal products, except machinery and equipment (5.1\%)

Basic metals (3.6\%)

Other domestic intermediate inputs (31.2\%)

\section{Imported intermediate inputs}

Motor vehicles, trailers and semi-trailers sector $(13.9 \%)$

Machinery and equipment n.e.c. $(2.3 \%)$

Other imported intermediate inputs (10.6\%)

Basic pharmaceutical products \& prep.

\section{Domestic intermediate inputs}

Sewerage; waste collection, treatment and disposal activities; materials recovery; remediation activities and other waste management services (7.3\%)

Basic pharmaceutical products \& prep. (7.2\%)

Scientific R\&D services (7.0\%)

Wholesale trade services exc. of motor (6.8\%)

Other domestic intermediate inputs (36.5\%)

\section{Imported intermediate inputs}

Chemicals and chemical products (11.3\%)

Basic pharmaceutical products \& prep. (10.3\%)

Other imported intermediate inputs (13.7\%) 


\section{Appendix 2: Detailed consumption of intermediate inputs (observed}

\section{sectors in the US) -Eurostat}

\section{Chemicals and chemical products}

\begin{tabular}{|c|}
\hline Domestic intermediate inputs \\
\hline $\begin{array}{c}\text { Chemicals and chemical products } \\
(36.2 \%)\end{array}$ \\
\hline \hline Coke and refined petroleum products (5.8\%) \\
\hline \hline $\begin{array}{c}\text { Wholesale trade services, except of motor } \\
\text { vehicles and motorcvcles (5.7\%) }\end{array}$ \\
\hline $\begin{array}{c}\text { Legal and accounting services; services of head } \\
\text { offices: management consulting services (5.1\%) }\end{array}$ \\
\hline \hline Other domestic intermediate inputs (35.0\%) \\
\hline
\end{tabular}

\section{Imported intermediate inputs}

Chemicals and chemical products

$(5.9 \%)$

Mining and quarrying $(2.7 \%)$

Other imported intermediate inputs (3.4\%)

Computer, electronic and optical products

\section{Domestic intermediate inputs}

Computer, electronic \& optical products (19.7\%)

Wholesale trade services, except of motor vehicles and motorcycles (11.0\%)

Legal and accounting services; services of head offices: management consulting services (7.5\%)

\section{Publishing services (6.2\%)}

Other domestic intermediate inputs (36.0\%)

\section{Imported intermediate inputs}

Computer, electronic and optical products

$(14.7 \%)$

Basic metals (1.2\%)

Other imported intermediate inputs (3.7\%)
Motor vehicles, trailers and semi-trailers

\section{Domestic intermediate inputs}

Motor vehicles, trailers \& semi-trailers $(22.1 \%)$

Fabricated metal products, except machinery and equipment $(9.1 \%)$

Legal and accounting services; services of head offices: management consulting services $(8.1 \%)$

Wholesale trade services, except of motor vehicles and motorcycles $(6.2 \%)$

Other domestic intermediate inputs (36.5\%)

\begin{tabular}{|c|}
\hline Imported intermediate inputs \\
\hline $\begin{array}{c}\text { Motor vehicles, trailers and semi-trailers sector } \\
(9.0 \%)\end{array}$ \\
\hline \hline Computer, electronic \& optical products (1.8\%) \\
\hline \hline Other imported intermediate inputs (7.2\%) \\
\hline
\end{tabular}

Basic pharmaceutical products \& prep.

\section{Domestic intermediate inputs}

Basic pharmaceutical products \& prep. $(25.3 \%)$

Legal and accounting services; services of head offices; management consulting services(13.3\%)

Wholesale trade services, except of motor vehicles and motorcvcles $(11.2 \%)$

Scientific research and development services $(9.0 \%)$

Other domestic intermediate inputs (24.8\%)

\section{Imported intermediate inputs}

Basic pharmaceutical products \& prep. (13.3\%)

Chemicals and chemical products $(1.3 \%)$

Other imported intermediate inputs (1.8\%) 


\section{Appendix 3: Detailed consumption of intermediate inputs (observed}

\section{sectors in the $\mathbf{E U}$ ) -Eurostat}

\section{Chemicals and chemical products}

\begin{tabular}{|c|}
\hline Domestic intermediate inputs \\
\hline $\begin{array}{l}\text { Chemicals and chemical products } \\
\qquad(27.6 \%)\end{array}$ \\
\hline $\begin{array}{l}\text { Wholesale trade services, except of motor } \\
\text { vehicles and motorcycles }(6.8 \%)\end{array}$ \\
\hline Coke and refined petroleum products ( $4.9 \%)$ \\
\hline $\begin{array}{l}\text { Electricity, gas, steam and air-conditioning } \\
\qquad(4.3 \%)\end{array}$ \\
\hline Other domestic intermediate inputs (43.5\%) \\
\hline
\end{tabular}

\section{Imported intermediate inputs}

Chemicals and chemical products (4.8\%) Mining and quarrying (4.0\%)

Other imported intermediate inputs $(4.1 \%)$

Computer, electronic and optical products

\section{Domestic intermediate inputs}

Computer, electronic \& optical products (13.3\%)

Wholesale trade services, except of motor vehicles and motorcycles (8.1\%)

Scientific research and development services (5.9\%)

Legal and accounting services; services of head offices; management consulting services (3.5\%)

Other domestic intermediate inputs $(47.2 \%)$

\section{Imported intermediate inputs}

Computer, electronic and optical products

$$
\text { (15.8\%) }
$$

Electrical equipment (1.1\%)

Other imported intermediate inputs $(5.1 \%)$
Motor vehicles, trailers and semi-trailers

\section{Domestic intermediate inputs}

Motor vehicles, trailers \& semi-trailers $(30.4 \%)$

Fabricated metal products, except machinery and equipment $(7.6 \%)$

Basic metals (6.0\%)

Rubber and plastics products $(5.2 \%)$

Other domestic intermediate inputs (43.7\%)

\section{Imported intermediate inputs}

Motor vehicles, trailers and semi-trailers sector

$$
(1.5 \%)
$$

Machinery and equipment n.e.c. (1.2\%)

Other imported intermediate inputs (4.4\%)

Basic pharmaceutical products \& prep.

\section{Domestic intermediate inputs}

Basic pharmaceutical products \& prep. (12.5\%)

Chemicals and chemical products (10.1\%)

Rental and leasing services (9.9\%)

Wholesale trade services, except of motor vehicles and motorcycles ( $8.7 \%)$

Other domestic intermediate inputs (46.7\%)

Imported intermediate inputs

Basic pharmaceutical products \& prep. (6.2\%)

Chemicals and chemical products $(2.0 \%)$

Other imported intermediate inputs (3.9\%) 


\section{Appendix 4: Detailed consumption of intermediate inputs of the}

\section{machinery and equipment n.e.c. -Eurostat}

\section{Machinery and equipment n.e.c in the EU}

\section{Domestic intermediate inputs}

Machinery and equipment n.e.c. (17.1\%)

Fabricated metal products, except machinery and equipment (14.5\%)

Basic metals

(8.1\%)

Wholesale trade services, except of motor vehicles and motorcycles (7.4\%)

Other domestic intermediate inputs (43.9\%)

\begin{tabular}{|c|}
\hline Imported intermediate inputs \\
\hline Machinery and equipment n.e.c. (3.0\%) \\
\hline $\begin{array}{c}\text { Computer, electronic and optical products } \\
(1.5 \%)\end{array}$ \\
\hline \hline Other imported intermediate inputs (4.5\%) \\
\hline
\end{tabular}

Machinery and equipment n.e.c in Germany

\section{Domestic intermediate inputs}

Machinery and equipment n.e.c.

$$
(20.3 \%)
$$

Fabricated metal products, except machinery and equipment $(9.7 \%)$

Wholesale trade services, except of motor vehicles and motorcycles (6.7\%)

Basic metals (4.6\%)

Other domestic intermediate inputs (35.3\%)

\section{Imported intermediate inputs}

Machinery and equipment n.e.c.

$$
\text { (9.4\%) }
$$

Basic metals (2.9\%)

Other imported intermediate inputs (1.1\%)
Machinery and equipment n.e.c in the US

\begin{tabular}{l} 
Domestic intermediate inputs \\
\begin{tabular}{|c|}
\hline $\begin{array}{c}\text { Fabricated metal products, except machinery } \\
\text { and equipment (14.3\%) }\end{array}$ \\
\hline \hline Basic metals (11.5\%) \\
\hline \hline Machinery and equipment n.e.c. \\
$(9.4 \%)$
\end{tabular} \\
\hline
\end{tabular}

Wholesale trade services, except of motor vehicles and motorcycles (8.4\%)

Other domestic intermediate inputs (41.8\%)

Imported intermediate inputs
\begin{tabular}{|c|}
\hline $\begin{array}{c}\text { Basic metals } \\
(3.3 \%)\end{array}$ \\
\hline \hline Machinery and equipment n.e.c. (2.9\%) \\
\hline \hline Other imported intermediate inputs (8.4\%) \\
\hline
\end{tabular}




\section{Appendix 5: The impact of 20\% increase in export of each observed sector on sectoral employment}

The impact of $20 \%$ increase in export of chemicals and chemical products

\begin{tabular}{|l|r|}
\hline \multicolumn{1}{|c|}{ Sector } & $\Delta$ Labor \\
\hline Total & 129,327 \\
\hline Chemicals and chemical products & 54,694 \\
\hline $\begin{array}{l}\text { Security and investigation services; services to buildings and landscape; office administrative, } \\
\text { office support and other business support services }\end{array}$ & 9,947 \\
\hline Wholesale trade services, except for motor vehicles and motorcycles & 6,625 \\
\hline Legal and accounting services; services of head offices; management consulting services & 5,716 \\
\hline Land transport services and transport services via pipelines & 3,993 \\
\hline Employment services & 3,421 \\
\hline Advertising and market research services & 3,390 \\
\hline Architectural and engineering services; technical testing and analysis services & 3,324 \\
\hline Public administration and defense services; compulsory social security services & 2,463 \\
\hline Constructions and construction works & 2,380 \\
\hline
\end{tabular}

The impact of $20 \%$ increase in export of computer, electronic and optical products

\begin{tabular}{|l|r|}
\hline \multicolumn{1}{|c|}{ Sector } & $\Delta$ Labor \\
\hline Total & 115,972 \\
\hline Computer, electronic and optical products & 64,950 \\
\hline Wholesale trade services, except of motor vehicles and motorcycles & 6,446 \\
\hline Retail trade services, except of motor vehicles and motorcycles & 5,051 \\
\hline $\begin{array}{l}\text { Security and investigation services; services to buildings and landscape; office administrative, } \\
\text { office support and other business support services }\end{array}$ & 4,728 \\
\hline Legal and accounting services; services of head offices; management consulting services & 3,275 \\
\hline Employment services & 2,757 \\
\hline Fabricated metal products, except machinery and equipment & 2,304 \\
\hline Architectural and engineering services; technical testing and analysis services & 2,235 \\
\hline Warehousing and support services for transportation & 2,232 \\
\hline Land transport services and transport services via pipelines & 2,042 \\
\hline
\end{tabular}

The impact of $20 \%$ increase in export of motor vehicles, trailers and semi-trailers

\begin{tabular}{|l|r|}
\hline \multicolumn{1}{|c|}{ Sector } & $\Delta$ Labor \\
\hline Total & 378,479 \\
\hline Motor vehicles, trailers and semi-trailers & 159,590 \\
\hline Wholesale and retail trade and repair services of motor vehicles and motorcycles & 24,992 \\
\hline Fabricated metal products, except machinery and equipment & 21,215 \\
\hline
\end{tabular}




\begin{tabular}{|l|r|}
\hline $\begin{array}{l}\text { Security and investigation services; services to buildings and landscape; office administrative, } \\
\text { office support and other business support services }\end{array}$ & 18,195 \\
\hline Legal and accounting services; services of head offices; management consulting services & 15,869 \\
\hline Employment services & 12,452 \\
\hline Wholesale trade services, except of motor vehicles and motorcycles & 12,372 \\
\hline Rubber and plastics products & 9,759 \\
\hline Land transport services and transport services via pipelines & 9,237 \\
\hline Warehousing and support services for transportation & 8,648 \\
\hline
\end{tabular}

The impact of $\mathbf{2 0 \%}$ increase in export of basic pharmaceutical products and pharmaceutical preparations

\begin{tabular}{|l|r|}
\hline \multicolumn{1}{|c|}{ Sector } & \multicolumn{1}{|c|}{ Labor } \\
\hline Total & 54,176 \\
\hline Basic pharmaceutical products and pharmaceutical preparations & 24,132 \\
\hline Retail trade services, except of motor vehicles and motorcycles & 4,081 \\
\hline $\begin{array}{l}\text { Security and investigation services; services to buildings and landscape; office administrative, } \\
\text { office support and other business support services }\end{array}$ & 2,830 \\
\hline Wholesale trade services, except of motor vehicles and motorcycles & 2,483 \\
\hline Scientific research and development services & 1,955 \\
\hline Employment services & 1,916 \\
\hline Legal and accounting services; services of head offices; management consulting services & 1,866 \\
\hline Advertising and market research services & 1,629 \\
\hline $\begin{array}{l}\text { Sewerage; waste collection, treatment and disposal activities; materials recovery; remediation } \\
\text { activities and other waste management services }\end{array}$ & 1,295 \\
\hline Architectural and engineering services; technical testing and analysis services & 1,212 \\
\hline
\end{tabular}

The impact of $20 \%$ increase in export of machinery and equipment n.e.c.

\begin{tabular}{|l|r|}
\hline \multicolumn{1}{|c|}{ Sector } & \multicolumn{1}{|c|}{$\Delta$ Labor } \\
\hline Total & 359,154 \\
\hline Machinery and equipment n.e.c. & 194,344 \\
\hline Fabricated metal products, except machinery and equipment & 23,386 \\
\hline Wholesale trade services, except of motor vehicles and motorcycles & 15,750 \\
\hline Employment services & 14,101 \\
\hline $\begin{array}{l}\text { Security and investigation services; services to buildings and landscape; office administrative, } \\
\text { office support and other business support services }\end{array}$ & 13,759 \\
\hline Legal and accounting services; services of head offices; management consulting services & 12,091 \\
\hline Warehousing and support services for transportation & 6,634 \\
\hline Retail trade services, except of motor vehicles and motorcycles & 6,476 \\
\hline Land transport services and transport services via pipelines & 5,838 \\
\hline Basic metals & 5,776 \\
\hline
\end{tabular}




\section{Appendix 6: The impact of an increase in exports due to TTIP agreement on Germany sectoral output and employment}

\begin{tabular}{|c|c|c|}
\hline Sector & $\Delta$ Output & $\Delta$ Labor \\
\hline Products of agriculture, hunting and related services & $-0.09 \%$ & -535 \\
\hline Products of forestry, logging and related services & $0.06 \%$ & 23 \\
\hline Fish and other fishing products; aquaculture products; support services to fishing & $0.05 \%$ & 2 \\
\hline Mining and quarrying & $0.17 \%$ & 139 \\
\hline Food products, beverages and tobacco products & $0.22 \%$ & 1865 \\
\hline Textiles, wearing apparel and leather products & $0.88 \%$ & 1497 \\
\hline Wood and of products of wood and cork, except furniture; articles of straw \& plaiting & $0.10 \%$ & 141 \\
\hline Paper and paper products & $0.17 \%$ & 231 \\
\hline Printing and recording services & $0.33 \%$ & 694 \\
\hline Coke and refined petroleum products & $0.87 \%$ & 254 \\
\hline Chemicals and chemical products & $0.84 \%$ & 2805 \\
\hline Basic pharmaceutical products and pharmaceutical preparations & $0.88 \%$ & 1100 \\
\hline Rubber and plastics products & $0.75 \%$ & 2784 \\
\hline Other non-metallic mineral products & $0.42 \%$ & 951 \\
\hline Basic metals & $0.95 \%$ & 2706 \\
\hline Fabricated metal products, except machinery and equipment & $0.25 \%$ & 2142 \\
\hline Computer, electronic and optical products & $-0.17 \%$ & -676 \\
\hline Electrical equipment & $-0.16 \%$ & -744 \\
\hline Machinery and equipment n.e.c. & $0.80 \%$ & 8308 \\
\hline Motor vehicles, trailers and semi-trailers & $1.60 \%$ & 13262 \\
\hline Other transport equipment & $0.28 \%$ & 391 \\
\hline Furniture; other manufactured goods & $0.26 \%$ & 990 \\
\hline Repair and installation services of machinery and equipment & $0.44 \%$ & 704 \\
\hline Electricity, gas, steam and air-conditioning & $0.06 \%$ & 162 \\
\hline Natural water; water treatment and supply services & $0.03 \%$ & 12 \\
\hline Sewerage; waste collection, treatment and disposal activities; materials recovery, etc & $-0.03 \%$ & -52 \\
\hline Constructions and construction works & $-0.03 \%$ & -731 \\
\hline Wholesale and retail trade and repair services of motor vehicles and motorcycles & $0.10 \%$ & 797 \\
\hline Wholesale trade services, except of motor vehicles and motorcycles & $0.03 \%$ & 598 \\
\hline Retail trade services, except of motor vehicles and motorcycles & $-0.18 \%$ & -5930 \\
\hline Land transport services and transport services via pipelines & $0.30 \%$ & 2531 \\
\hline Water transport services & $-0.04 \%$ & -13 \\
\hline Air transport services & $0.87 \%$ & 549 \\
\hline Warehousing and support services for transportation & $0.19 \%$ & 1137 \\
\hline Postal and courier services & $0.42 \%$ & 1726 \\
\hline Accommodation and food services & $-0.21 \%$ & -3433 \\
\hline
\end{tabular}


Appendix 6: The impact of an increase in exports due to TTIP agreement on Germany sectoral output and employment (continued)

\begin{tabular}{|c|c|c|}
\hline Sector & $\Delta$ Output & $\Delta$ Labor \\
\hline Publishing services & $-0.05 \%$ & -144 \\
\hline $\begin{array}{l}\text { Motion picture, video and television programme production services, sound recording } \\
\text { and music publishing; programming and broadcasting services }\end{array}$ & $-0.04 \%$ & -54 \\
\hline Telecommunications services & $1.04 \%$ & 1765 \\
\hline Computer programming, consultancy and related services; information services & $0.61 \%$ & 4027 \\
\hline Financial services, except insurance and pension funding & $0.13 \%$ & 906 \\
\hline Insurance, reinsurance and pension funding services, except compulsory social security & $-0.12 \%$ & -237 \\
\hline Services auxiliary to financial services and insurance services & $-0.07 \%$ & -226 \\
\hline Real estate services (exluding imputed rent) & $0.06 \%$ & 250 \\
\hline $\begin{array}{l}\text { Legal and accounting services; services of head offices; management consulting } \\
\text { services }\end{array}$ & $0.40 \%$ & 4640 \\
\hline Architectural and engineering services; technical testing and analysis services & $0.58 \%$ & 3280 \\
\hline Scientific research and development services & $0.64 \%$ & 1053 \\
\hline Advertising and market research services & $0.44 \%$ & 1226 \\
\hline Other professional, scientific and technical services; veterinary services & $0.52 \%$ & 1075 \\
\hline Rental and leasing services & $0.12 \%$ & 163 \\
\hline Employment services & $0.36 \%$ & 2310 \\
\hline Travel agency, tour operator and other reservation services and related services & $0.14 \%$ & 142 \\
\hline $\begin{array}{l}\text { Security and investigation services; services to buildings and landscape; office } \\
\text { administrative, office support and other business support services }\end{array}$ & $0.29 \%$ & 4785 \\
\hline Public administration and defence services; compulsory social security services & $-0.20 \%$ & -5586 \\
\hline Education services & $-0.23 \%$ & -5681 \\
\hline Human health services & $-0.25 \%$ & -6284 \\
\hline Social work services & $-0.26 \%$ & -4498 \\
\hline $\begin{array}{l}\text { Creative, arts and entertainment services; library, archive, museum and other cultural } \\
\text { services; gambling and betting services }\end{array}$ & $-0.21 \%$ & -824 \\
\hline Sporting services and amusement and recreation services & $-0.20 \%$ & -469 \\
\hline Services furnished by membership organisations & $-0.15 \%$ & -1086 \\
\hline Repair services of computers and personal and household goods & $0.04 \%$ & 34 \\
\hline Other personal services & $-0.13 \%$ & -982 \\
\hline
\end{tabular}




\section{Appendix 7: US FDI Outward to the European Union Countries}

\begin{tabular}{|c|c|c|c|c|c|c|c|c|c|c|c|c|c|c|}
\hline Country & 1999 & 2000 & 2001 & 2002 & 2003 & 2004 & 2005 & 2006 & 2007 & 2008 & 2009 & 2010 & 2011 & 2012 \\
\hline Austria & 3848 & 2872 & 3964 & 4011 & 6366 & 9264 & 11236 & 14897 & 14646 & 13546 & 10954 & 11485 & 13763 & 15591 \\
\hline Belgium & 21756 & 17973 & 22589 & 25727 & 27415 & 41840 & 49306 & 51862 & 62491 & 65279 & 46610 & 43975 & 50941 & 53769 \\
\hline Czech Rep. & 1038 & 1228 & 1179 & 1264 & 1668 & 2444 & 2729 & 3615 & 4066 & 5053 & 5372 & 5268 & 5804 & 6389 \\
\hline Denmark & 3846 & 5270 & 5160 & 6184 & 5597 & 6815 & 6914 & 5849 & 8950 & 10481 & 13053 & 11802 & 15019 & 15092 \\
\hline Finland & 1379 & 1342 & 1686 & 1722 & 1677 & 2208 & 1950 & 2107 & 2202 & 2012 & 1659 & 1597 & 2184 & 2013 \\
\hline France & 43120 & 42628 & 40125 & 43348 & 51229 & 63359 & 60526 & 63008 & 74179 & 84409 & 90879 & 78320 & 79621 & 82596 \\
\hline Germany & 53399 & 55508 & 63396 & 61073 & 72262 & 79467 & 100473 & 93620 & 100601 & 107833 & 110149 & 103319 & 111088 & 121184 \\
\hline Greece & 760 & 795 & 835 & 981 & 1431 & 1899 & 1884 & 1804 & 2179 & 2092 & 1919 & 1775 & 1189 & 969 \\
\hline Hungary & 2409 & 1920 & 2033 & 2503 & 2856 & 3024 & 2795 & 2602 & 6457 & 3737 & 4090 & 4237 & 5651 & 6014 \\
\hline Ireland & 25157 & 35903 & 39541 & 51598 & 60604 & 72907 & 55173 & 86372 & 117708 & 150131 & 129829 & 158851 & 189449 & 203779 \\
\hline Italy & 17889 & 23484 & 22883 & 23771 & 23092 & 25184 & 24528 & 25435 & 28216 & 27663 & 29944 & 27137 & 25981 & 26754 \\
\hline Luxembourg & 22148 & 27849 & 50771 & 62181 & 68298 & 83634 & 79937 & 125146 & 144180 & 172251 & 219082 & 272206 & 350619 & 383603 \\
\hline Netherlands & 121315 & 115429 & 147687 & 158415 & 186366 & 219384 & 240205 & 279373 & 412122 & 423059 & 497471 & 514689 & 573721 & 645098 \\
\hline Poland & 3281 & 3884 & 4573 & 4231 & 4382 & 7256 & 5575 & 6934 & 15614 & 12489 & 13412 & 13152 & 13446 & 14178 \\
\hline Portugal & 2188 & 2664 & 2746 & 3093 & 2402 & 1915 & 2138 & 2832 & 2991 & 3006 & 2803 & 2612 & 2477 & 2383 \\
\hline Spain & 19970 & 21236 & 28174 & 38001 & 41119 & 48409 & 50197 & 49356 & 61093 & 54194 & 58341 & 52390 & 48581 & 31377 \\
\hline Sweden & 10624 & 25959 & 26374 & 30114 & 27004 & 29730 & 30153 & 33857 & 36615 & 35876 & 36702 & 23275 & 24827 & 24532 \\
\hline United Kingdom & 216638 & 230762 & 228230 & 247952 & 277246 & 330416 & 351513 & 406358 & 426357 & 448412 & 495382 & 501247 & 515991 & 597813 \\
\hline
\end{tabular}

Source: BEA United States 


\section{Appendix 8: US FDI Inward from the European Union Countries}

\begin{tabular}{|c|c|c|c|c|c|c|c|c|c|c|c|c|c|c|}
\hline Country & 1999 & 2000 & 2001 & 2002 & 2003 & 2004 & 2005 & 2006 & 2007 & 2008 & 2009 & 2010 & 2011 & 2012 \\
\hline Austria & 3216 & 3007 & 2743 & 3596 & 3606 & 3572 & 2425 & 2305 & 4410 & 4251 & 4622 & 4532 & 4753 & 5206 \\
\hline Belgium & 11011 & 14787 & 15623 & 9777 & 11239 & 12581 & 10024 & 11691 & 23471 & 23379 & 36292 & 69565 & 80299 & 88697 \\
\hline Denmark & 5215 & 4025 & 1857 & 4215 & 4531 & 5064 & 6117 & 6726 & 5761 & 5537 & 6806 & 7772 & 8826 & 8807 \\
\hline Finland & 4816 & 8875 & 7620 & 6133 & 5300 & 5639 & 5938 & 7129 & 5308 & 7613 & 5415 & 4943 & 5908 & 7162 \\
\hline France & 89945 & 125740 & 154984 & 133914 & 136434 & 137927 & 114260 & 147799 & 141487 & 141922 & 158924 & 189763 & 189629 & 209121 \\
\hline Germany & 112126 & 122412 & 162314 & 138301 & 160691 & 164921 & 177176 & 205969 & 187815 & 173843 & 183966 & 203077 & 215250 & 199006 \\
\hline Ireland & 14958 & 25523 & 25632 & 27302 & 23346 & 16446 & 17465 & 25517 & 26089 & 21270 & 21044 & 24097 & 23410 & 24917 \\
\hline Italy & 4444 & 6576 & 6826 & 6830 & 6944 & 6889 & 7725 & 9299 & 13762 & 19466 & 18567 & 20142 & 21272 & 23260 \\
\hline Luxembourg & 35644 & 58930 & 95299 & 97416 & 109212 & 116479 & 79680 & 89157 & 123389 & 130020 & 138667 & 170309 & 192860 & 202338 \\
\hline Netherlands & 125010 & 138894 & 145554 & 145596 & 146601 & 159601 & 156602 & 182014 & 184613 & 179938 & 206622 & 234408 & 225703 & 274904 \\
\hline Spain & 2749 & 5068 & 4659 & 4612 & 5670 & 5818 & 7472 & 13969 & 25908 & 30037 & 38984 & 43095 & 46177 & 47352 \\
\hline Sweden & 18954 & 21991 & 20804 & 20504 & 20156 & 22292 & 22269 & 20098 & 45811 & 32578 & 28941 & 38780 & 39388 & 42387 \\
\hline United Kingdom & 153797 & 277613 & 197651 & 211699 & 217841 & 267209 & 371350 & 414629 & 405543 & 447529 & 414590 & 400435 & 461701 & 486833 \\
\hline
\end{tabular}

Source: BEA United States 


\section{Appendix 9: US FDI Outward to Germany (Historical Basis / Stock)}

\begin{tabular}{|c|c|c|c|c|c|c|c|c|c|c|c|c|c|c|}
\hline Sector & 1999 & 2000 & 2001 & 2002 & 2003 & 2004 & 2005 & 2006 & 2007 & 2008 & 2009 & 2010 & 2011 & 2012 \\
\hline TOTAL & 53399 & 55508 & 63396 & 61073 & 72262 & 79467 & 100473 & 93620 & 100601 & 107833 & 110149 & 103319 & 111088 & 121184 \\
\hline Total Manufacturing & 27040 & 29246 & 21305 & 16497 & 16812 & 21429 & 22904 & 27503 & 28395 & 25050 & 28899 & 25347 & 27593 & 35105 \\
\hline Chemicals & 2944 & 2079 & 6260 & 2336 & 2789 & 2900 & 3672 & 4641 & 6216 & 6283 & 6847 & 3873 & 4423 & 4861 \\
\hline Machinery & 1740 & 1866 & 1270 & 1370 & 1109 & 2243 & 2325 & 2519 & 3197 & 3380 & 3438 & 3581 & 4531 & 5005 \\
\hline $\begin{array}{l}\text { Computers and } \\
\text { Electronic Products }\end{array}$ & 4341 & 5967 & 2631 & 2169 & 2914 & 3231 & 4592 & 3762 & 3591 & 3889 & 5323 & 5148 & 3843 & 8375 \\
\hline $\begin{array}{l}\text { Transportation } \\
\text { Equipment }\end{array}$ & 11798 & 10917 & 4528 & 4092 & 3726 & 4271 & 3797 & 7244 & 7214 & 996 & 4853 & 3563 & 4428 & 4623 \\
\hline
\end{tabular}

Source: BEA United States 


\section{Appendix 10: US FDI Inward from Germany (Historical Basis / Stock)}

\begin{tabular}{|c|c|c|c|c|c|c|c|c|c|c|c|c|c|c|}
\hline Sector & 1999 & 2000 & 2001 & 2002 & 2003 & 2004 & 2005 & 2006 & 2007 & 2008 & 2009 & 2010 & 2011 & 2012 \\
\hline TOTAL & 112126 & 122412 & 162314 & 138301 & 160691 & 164921 & 177176 & 205969 & 187815 & 173843 & 183966 & 203077 & 215250 & 199006 \\
\hline Total Manufacturing & 55269 & 59090 & 56629 & 51176 & 53184 & 55842 & 66270 & 66167 & 54005 & 53018 & 52912 & 66200 & 72781 & 67429 \\
\hline Chemicals & 18548 & 17799 & 18919 & 17899 & 19603 & 21142 & 25088 & 26327 & 21374 & 22729 & 23991 & 22517 & 18639 & 15808 \\
\hline Machinery & 2949 & 2999 & 8708 & 6709 & 5482 & 6110 & (D) & (D) & 8925 & 8411 & 9044 & 8884 & 16104 & 13484 \\
\hline $\begin{array}{l}\text { Computers and } \\
\text { Electronic Products }\end{array}$ & 679 & 540 & 421 & 780 & 707 & 415 & 754 & 818 & 801 & 651 & 732 & 1293 & 1155 & 1106 \\
\hline $\begin{array}{l}\text { Transportation } \\
\text { Equipment }\end{array}$ & 24496 & (D) & 19117 & 16638 & 17756 & 19700 & 21421 & 17310 & 14436 & 12165 & 10699 & 18456 & 18816 & 19747 \\
\hline
\end{tabular}

Source: BEA United States

(D) --> indicates that the data in the cell have been suppressed to avoid disclosure of data of individual companies. 


\section{Appendix 11: Sector' share in value added as a percent of total value added -Eurostat}

\begin{tabular}{|c|c|c|c|}
\hline Sector & Germany & $\overline{\mathbf{E U}}$ & $\mathbf{U S}$ \\
\hline Agriculture subtotal & $0.96 \%$ & $2.16 \%$ & $2.53 \%$ \\
\hline Products of agriculture, hunting and related services & $0.61 \%$ & $1.26 \%$ & $0.79 \%$ \\
\hline Products of forestry, logging and related services & $0.09 \%$ & $0.15 \%$ & $0.21 \%$ \\
\hline Fish and other fishing products; aquaculture products; support services to fishing & $0.01 \%$ & $0.05 \%$ & $0.02 \%$ \\
\hline Mining and quarrying & $0.25 \%$ & $0.70 \%$ & $1.51 \%$ \\
\hline Manufacture subtotal & $17.57 \%$ & $14.12 \%$ & $10.91 \%$ \\
\hline Food products, beverages and tobacco products & $1.59 \%$ & $2.13 \%$ & $1.63 \%$ \\
\hline Chemicals and chemical products & $1.21 \%$ & $0.94 \%$ & $0.96 \%$ \\
\hline Basic pharmaceutical products and pharmaceutical preparations & $0.64 \%$ & $0.62 \%$ & $0.73 \%$ \\
\hline Rubber and plastics products & $0.93 \%$ & $0.67 \%$ & $0.46 \%$ \\
\hline Basic metals & $0.73 \%$ & $0.54 \%$ & $0.26 \%$ \\
\hline Fabricated metal products, except machinery and equipment & $1.78 \%$ & $1.37 \%$ & $0.77 \%$ \\
\hline Computer, electronic and optical products & $0.84 \%$ & $0.61 \%$ & $1.36 \%$ \\
\hline Electrical equipment & $1.34 \%$ & $0.69 \%$ & $0.31 \%$ \\
\hline Machinery and equipment n.e.c. & $2.83 \%$ & $1.37 \%$ & $0.75 \%$ \\
\hline Motor vehicles, trailers and semi-trailers & $1.73 \%$ & $0.90 \%$ & $0.39 \%$ \\
\hline Utilities & $3.18 \%$ & $3.07 \%$ & $2.75 \%$ \\
\hline Electricity, gas, steam and air-conditioning & $2.08 \%$ & $2.08 \%$ & $2.13 \%$ \\
\hline $\begin{array}{l}\text { Sewerage; waste collection, treatment and disposal activities; materials recovery; } \\
\text { remediation activities and other waste management services }\end{array}$ & $0.88 \%$ & $0.75 \%$ & $0.40 \%$ \\
\hline Services & $78.29 \%$ & $80.65 \%$ & $83.80 \%$ \\
\hline Constructions and construction works & $4.68 \%$ & $6.73 \%$ & $4.08 \%$ \\
\hline Wholesale trade services, except of motor vehicles and motorcycles & $5.18 \%$ & $5.08 \%$ & $5.58 \%$ \\
\hline Retail trade services, except of motor vehicles and motorcycles & $4.06 \%$ & $4.24 \%$ & $5.59 \%$ \\
\hline Land transport services and transport services via pipelines & $1.54 \%$ & $2.34 \%$ & $1.70 \%$ \\
\hline Accommodation and food services & $1.87 \%$ & $3.15 \%$ & $3.03 \%$ \\
\hline Telecommunications services & $1.12 \%$ & $1.61 \%$ & $2.05 \%$ \\
\hline Computer programming, consultancy and related services; information services & $1.99 \%$ & $2.01 \%$ & $2.48 \%$ \\
\hline Financial services, except insurance and pension funding & $2.94 \%$ & $3.95 \%$ & $3.43 \%$ \\
\hline Real estate services (excluding imputed rent) & $13.05 \%$ & $7.37 \%$ & $5.81 \%$ \\
\hline $\begin{array}{l}\text { Legal and accounting services; services of head offices; management consulting } \\
\text { services }\end{array}$ & $3.26 \%$ & $3.13 \%$ & $4.85 \%$ \\
\hline Architectural and engineering services; technical testing and analysis services & $1.48 \%$ & $1.41 \%$ & $1.16 \%$ \\
\hline Scientific research and development services & $0.57 \%$ & $0.62 \%$ & $0.62 \%$ \\
\hline Rental and leasing services & $2.15 \%$ & $1.38 \%$ & $1.65 \%$ \\
\hline Education services & $4.70 \%$ & $5.33 \%$ & $1.46 \%$ \\
\hline Human health services & $5.50 \%$ & $5.20 \%$ & $7.54 \%$ \\
\hline
\end{tabular}




\section{Appendix 12: Sector' expenditure on Scientific Research and Development}

Services (as a percentage of total intermediate input consumption) -

\section{Eurostat}

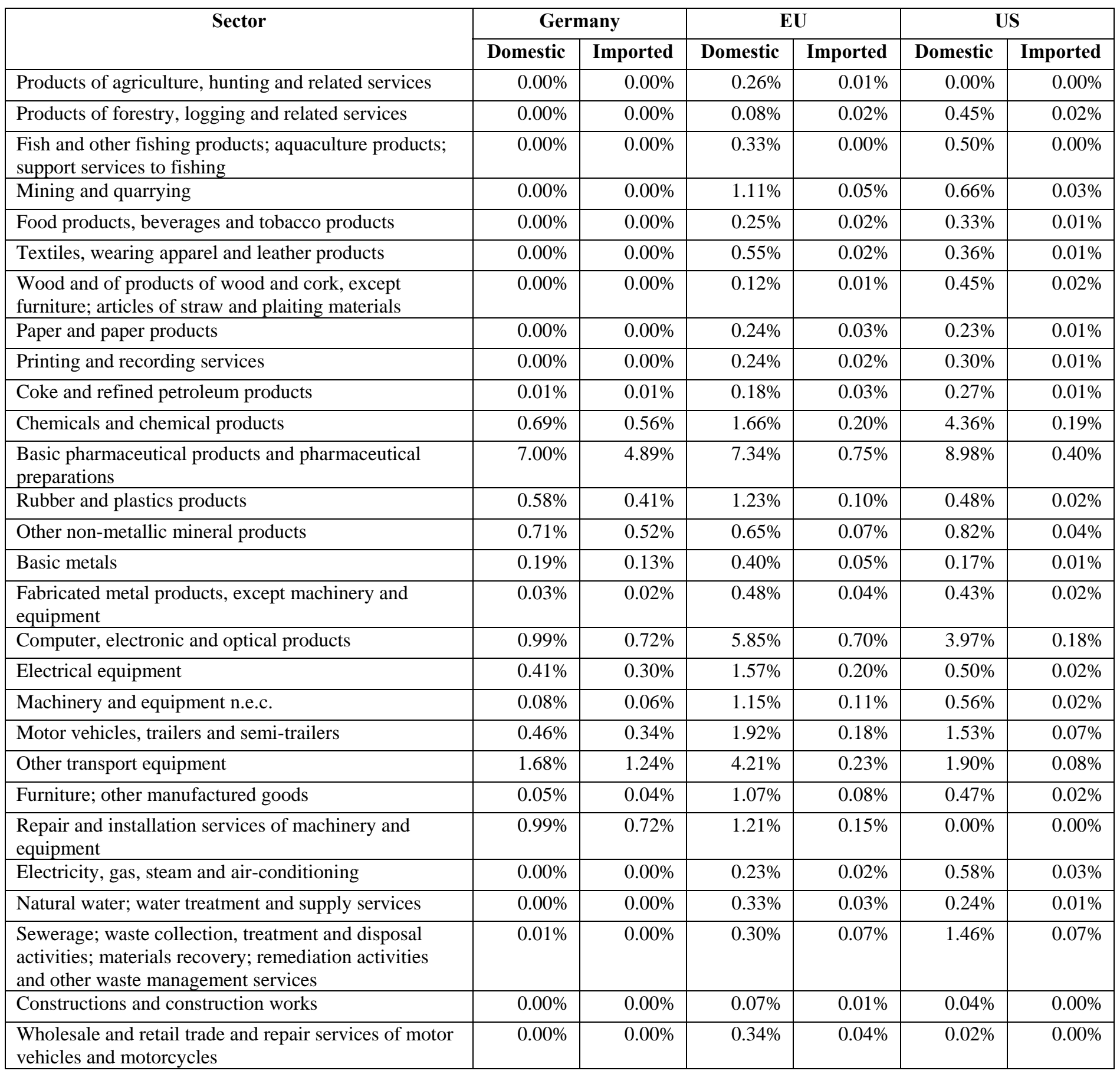




\section{Appendix 12: Sector' expenditure on Scientific Research and Development Services (as a percentage of total intermediate input consumption) - continued}

\begin{tabular}{|c|c|c|c|c|c|c|}
\hline \multirow[t]{2}{*}{ Sector } & \multicolumn{2}{|c|}{ Germany } & \multicolumn{2}{|c|}{$\mathbf{E U}$} & \multicolumn{2}{|c|}{$\mathbf{U S}$} \\
\hline & Domestic & Imported & Domestic & Imported & Domestic & Imported \\
\hline $\begin{array}{l}\text { Wholesale trade services, except of motor vehicles and } \\
\text { motorcycles }\end{array}$ & $0.03 \%$ & $0.02 \%$ & $0.44 \%$ & $0.05 \%$ & $1.79 \%$ & $0.08 \%$ \\
\hline $\begin{array}{l}\text { Retail trade services, except of motor vehicles and } \\
\text { motorcycles }\end{array}$ & $0.00 \%$ & $0.00 \%$ & $0.12 \%$ & $0.02 \%$ & $0.09 \%$ & $0.00 \%$ \\
\hline $\begin{array}{l}\text { Land transport services and transport services via } \\
\text { pipelines }\end{array}$ & $0.00 \%$ & $0.00 \%$ & $0.07 \%$ & $0.02 \%$ & $0.08 \%$ & $0.00 \%$ \\
\hline Air transport services & $0.00 \%$ & $0.00 \%$ & $0.09 \%$ & $0.02 \%$ & $0.00 \%$ & $0.00 \%$ \\
\hline Warehousing and support services for transportation & $0.00 \%$ & $0.00 \%$ & $0.07 \%$ & $0.02 \%$ & $0.01 \%$ & $0.00 \%$ \\
\hline Postal and courier services & $0.00 \%$ & $0.00 \%$ & $0.38 \%$ & $0.03 \%$ & $0.00 \%$ & $0.00 \%$ \\
\hline Accommodation and food services & $0.00 \%$ & $0.00 \%$ & $0.05 \%$ & $0.01 \%$ & $0.23 \%$ & $0.01 \%$ \\
\hline Telecommunications services & $0.24 \%$ & $0.18 \%$ & $1.69 \%$ & $0.07 \%$ & $0.31 \%$ & $0.01 \%$ \\
\hline $\begin{array}{l}\text { Computer programming, consultancy and related } \\
\text { services; information services }\end{array}$ & $0.02 \%$ & $0.02 \%$ & $1.46 \%$ & $0.25 \%$ & $0.68 \%$ & $0.03 \%$ \\
\hline $\begin{array}{l}\text { Financial services, except insurance and pension } \\
\text { funding }\end{array}$ & $0.00 \%$ & $0.00 \%$ & $0.11 \%$ & $0.01 \%$ & $0.43 \%$ & $0.02 \%$ \\
\hline $\begin{array}{l}\text { Insurance, reinsurance and pension funding services, } \\
\text { except compulsory social security }\end{array}$ & $0.00 \%$ & $0.00 \%$ & $0.06 \%$ & $0.01 \%$ & $0.00 \%$ & $0.00 \%$ \\
\hline $\begin{array}{l}\text { Services auxiliary to financial services and insurance } \\
\text { services }\end{array}$ & $0.00 \%$ & $0.00 \%$ & $0.03 \%$ & $0.00 \%$ & $0.04 \%$ & $0.00 \%$ \\
\hline Real estate services (excluding imputed rent) & $0.00 \%$ & $0.00 \%$ & $0.29 \%$ & $0.05 \%$ & $0.10 \%$ & $0.00 \%$ \\
\hline Imputed rents of owner-occupied dwellings & $0.00 \%$ & $0.00 \%$ & $0.00 \%$ & $0.00 \%$ & $0.00 \%$ & $0.00 \%$ \\
\hline $\begin{array}{l}\text { Other professional, scientific and technical services; } \\
\text { veterinary services }\end{array}$ & $0.00 \%$ & $0.00 \%$ & $0.62 \%$ & $0.08 \%$ & $0.15 \%$ & $0.01 \%$ \\
\hline Rental and leasing services & $0.00 \%$ & $0.00 \%$ & $0.34 \%$ & $0.07 \%$ & $0.26 \%$ & $0.01 \%$ \\
\hline Employment services & $0.00 \%$ & $0.00 \%$ & $0.29 \%$ & $0.08 \%$ & $0.13 \%$ & $0.00 \%$ \\
\hline $\begin{array}{l}\text { Travel agency, tour operator and other reservation } \\
\text { services and related services }\end{array}$ & $0.00 \%$ & $0.00 \%$ & $0.18 \%$ & $0.02 \%$ & $0.13 \%$ & $0.01 \%$ \\
\hline
\end{tabular}




\section{Appendix 12: Sector' expenditure on Scientific Research and Development Services (as a percentage of total intermediate input consumption) - continued}

\begin{tabular}{|l|r|r|r|r|r|r|}
\hline \multicolumn{1}{|c|}{ Sector } & \multicolumn{2}{|c|}{ Germany } & \multicolumn{2}{|c|}{ EU } & \multicolumn{2}{c|}{ US } \\
\cline { 2 - 7 } & Domestic & Imported & Domestic & Imported & Domestic & Imported \\
\hline $\begin{array}{l}\text { Security and investigation services; services to } \\
\text { buildings and landscape; office administrative, office } \\
\text { support and other business support services }\end{array}$ & $0.70 \%$ & $0.50 \%$ & $0.45 \%$ & $0.09 \%$ & $0.09 \%$ & $0.00 \%$ \\
\hline $\begin{array}{l}\text { Public administration and defense services; compulsory } \\
\text { social security services }\end{array}$ & $4.84 \%$ & $3.52 \%$ & $3.84 \%$ & $0.43 \%$ & $7.23 \%$ & $0.32 \%$ \\
\hline Education services & $3.51 \%$ & $2.17 \%$ & $1.13 \%$ & $0.26 \%$ & $4.62 \%$ & $0.20 \%$ \\
\hline Human health services & $0.24 \%$ & $0.17 \%$ & $0.37 \%$ & $0.16 \%$ & $0.72 \%$ & $0.03 \%$ \\
\hline Social work services & $0.29 \%$ & $0.22 \%$ & $0.26 \%$ & $0.03 \%$ & $0.09 \%$ & $0.00 \%$ \\
\hline $\begin{array}{l}\text { Creative, arts and entertainment services; library, } \\
\text { archive, museum and other cultural services; gambling } \\
\text { and betting services }\end{array}$ & $0.27 \%$ & $0.19 \%$ & $0.22 \%$ & $0.04 \%$ & $0.14 \%$ & $0.01 \%$ \\
\hline $\begin{array}{l}\text { Sporting services and amusement and recreation } \\
\text { services }\end{array}$ & $0.00 \%$ & $0.00 \%$ & $0.10 \%$ & $0.02 \%$ & $0.19 \%$ & $0.01 \%$ \\
\hline Services furnished by membership organizations & $0.00 \%$ & $0.00 \%$ & $0.23 \%$ & $0.11 \%$ & $0.32 \%$ & $0.01 \%$ \\
\hline $\begin{array}{l}\text { Repair services of computers and personal and } \\
\text { household goods }\end{array}$ & $0.00 \%$ & $0.00 \%$ & $0.35 \%$ & $0.06 \%$ & $0.00 \%$ & $0.00 \%$ \\
\hline Other personal services & $0.00 \%$ & $0.00 \%$ & $0.15 \%$ & $0.02 \%$ & $0.01 \%$ & $0.00 \%$ \\
\hline $\begin{array}{l}\text { Services of households as employers; undifferentiated } \\
\text { goods and services produced by households for own } \\
\text { use }\end{array}$ & $0.00 \%$ & $0.00 \%$ & $0.24 \%$ & $0.03 \%$ & $0.00 \%$ & $0.00 \%$ \\
\hline $\begin{array}{l}\text { Services provided by extraterritorial organizations and } \\
\text { bodies }\end{array}$ & $0.00 \%$ & $0.00 \%$ & $1.16 \%$ & $0.00 \%$ & $0.00 \%$ & $0.00 \%$ \\
\hline Total & $0.44 \%$ & $0.31 \%$ & $0.83 \%$ & $0.10 \%$ & $1.26 \%$ & $0.06 \%$ \\
\hline
\end{tabular}




\section{Appendix 13: Detailed Structure of Five Observed Sectors}

\begin{tabular}{|c|c|}
\hline Sector & Detailed sector \\
\hline \multirow{6}{*}{ Chemicals and chemical products } & $\begin{array}{l}\text { Manufacture of basic chemicals, fertilizers and nitrogen } \\
\text { compounds, plastics and synthetic rubber in primary forms, } \\
\text { including: } \\
\text { - Manufacture of industrial gases } \\
\text { - Manufacture of dyes and pigments } \\
\text { - Manufacture of other inorganic basic chemicals } \\
\text { - Manufacture of other organic basic chemicals } \\
\text { - Manufacture of fertilizers and nitrogen compounds } \\
\text { - Manufacture of plastics in primary forms } \\
\text { - Manufacture of synthetic rubber in primary forms }\end{array}$ \\
\hline & Manufacture of pesticides and other agrochemical products \\
\hline & $\begin{array}{l}\text { Manufacture of paints, varnishes and similar coatings, printing } \\
\text { ink and mastics }\end{array}$ \\
\hline & $\begin{array}{l}\text { Manufacture of soap and detergents, cleaning and polishing } \\
\text { preparations, perfumes and toilet preparations. }\end{array}$ \\
\hline & $\begin{array}{l}\text { Manufacture of other chemical products, including: } \\
\text { - Manufacture of explosives } \\
\text { - Manufacture of glues } \\
\text { - Manufacture of essential oils } \\
\text { - Manufacture of other chemical products n.e.c. }\end{array}$ \\
\hline & Manufacture of man-made fibres \\
\hline \multirow{8}{*}{$\begin{array}{l}\text { Computer, electronic and optical } \\
\text { products }\end{array}$} & Manufacture of electronic components and boards. \\
\hline & Manufacture of computers and peripheral equipment \\
\hline & Manufacture of communication equipment \\
\hline & Manufacture of consumer electronics \\
\hline & $\begin{array}{l}\text { Manufacture of instruments and appliances for measuring, } \\
\text { testing and navigation; watches and clocks, including: }\end{array}$ \\
\hline & $\begin{array}{l}\text { Manufacture of irradiation, electro-medical and } \\
\text { electrotherapeutic equipment }\end{array}$ \\
\hline & Manufacture of optical instruments and photographic equipment \\
\hline & Manufacture of magnetic and optical media \\
\hline \multirow[b]{3}{*}{$\begin{array}{l}\text { Motor vehicles, trailers and semi- } \\
\text { trailers }\end{array}$} & Manufacture of motor vehicles \\
\hline & $\begin{array}{l}\text { Manufacture of bodies (coachwork) for motor vehicles; } \\
\text { manufacture of trailers and semi-trailers }\end{array}$ \\
\hline & $\begin{array}{l}\text { Manufacture of parts and accessories for motor vehicles, } \\
\text { including: } \\
\text { - Manufacture of electrical and electronic equipment for motor } \\
\text { vehicles } \\
\text { - Manufacture of other parts and accessories for motor vehicles }\end{array}$ \\
\hline \multirow{2}{*}{$\begin{array}{l}\text { Basic pharmaceutical products and } \\
\text { pharmaceutical preparations }\end{array}$} & Manufacture of basic pharmaceutical products \\
\hline & Manufacture of pharmaceutical preparations \\
\hline
\end{tabular}




\section{Appendix 13: Detailed Structure of Five Observed Sectors (continued)}

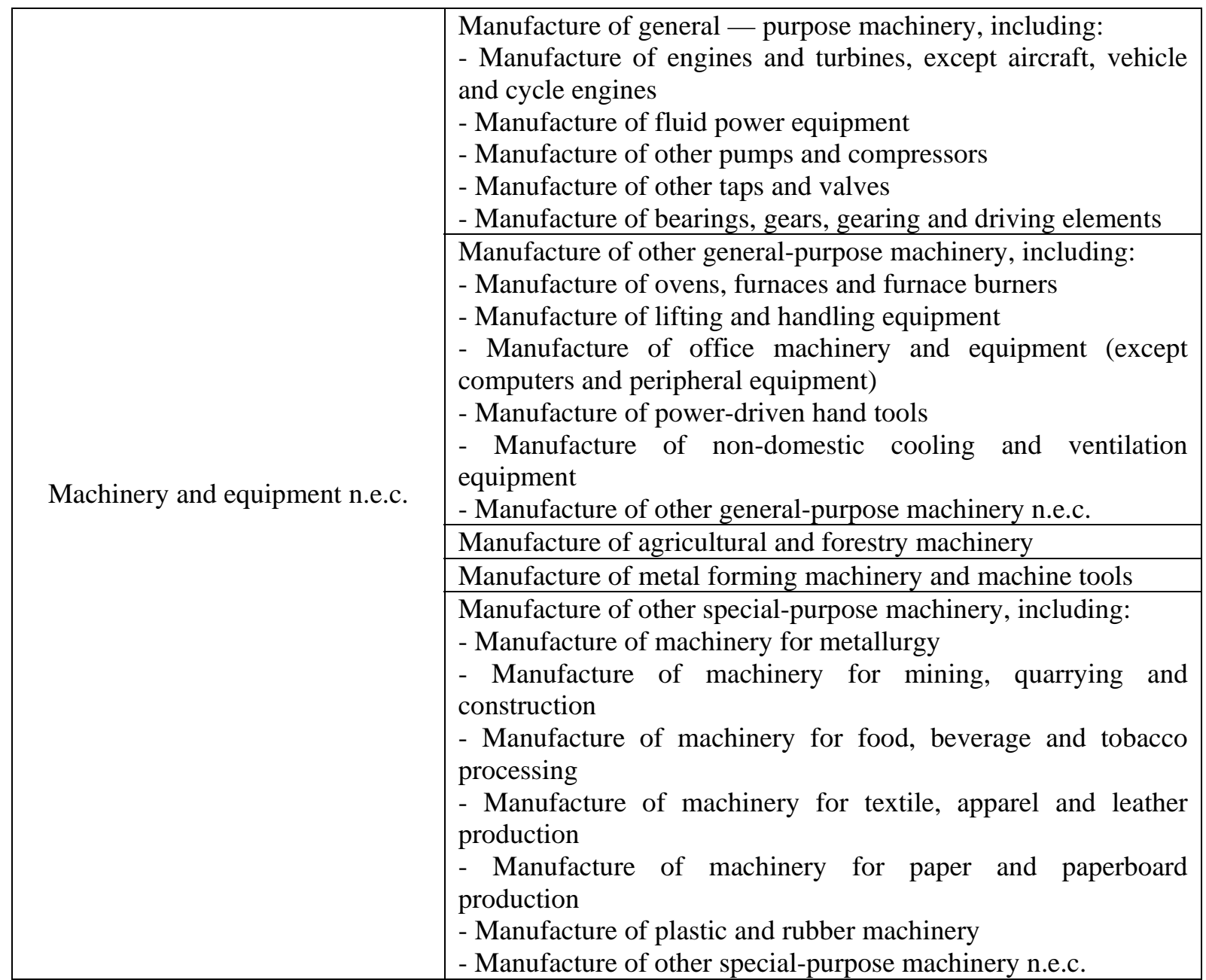

Source: Eurostats 